\title{
BLACKWATER FEVER.
}

\author{
By LEONARD S. DUDGEON, C.M.G., C.B.E., F.R.C.P. Lond., \\ Professor of Pathology in the University of London.
}

\begin{abstract}
SYNOPSIS.
Introduction

Section I. Abnormal changes found in the blood plasma, serum, and red blood corpuscles in blackwater fever. 1. Jaundice. 2. Haemoglobinaenia. 3. Observations on the blood cells. 4. On the serum reaction for syphilis. 5. Parasites: (a) Spirochaetes; (b) Malarial

Section II. The tissue changes in blackwater fever. The injection of "malarial melanin" into animals

Section III. On the extraction of the urine and tissues in blackwater fever for the presence

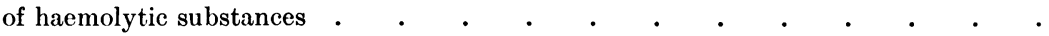

Section IV. The experimental production of haemoglobinaemia and haemoglobinuria in animals injected with immune sera

Section V. On quinine in relation to blackwater fever. (a) The administration of quinine previous to and during an attack of blackwater fever. (b) On the haemolytic action of quinine salts in urine and on the excretion of quinine in the urine in malaria and blackwater fever. (c) Quinine administration in rabbits, in which complete occlusion of the ureters had been performed

Section VI. On the examination of the urine in blackwater fever. 1. Agglutination of red cells in the urine. 2. On the presence of spirochaetes in the urine. 3. On the presence of acetone and diacetic acid. 4. On the presence of haemolytic substances in the urine. 5. On the injection of the urine from cases of blackwater fever into rabbits. 6. On the rapid changes which occur in the urine during an attack of blackwater fever. 7 . The colour of the urine
\end{abstract}

Section VII. The seasonal incidence of blackwater fever in relation to malaria and climatic conditions .

Summary

References

\section{INTRODUCTION.}

Tне investigations on blackwater fever herein described were made in the Balkans during 1916-17-18, while I was attached to the British Force there, and were completed in my laboratories at St Thomas's Hospital, in 1919 and 1920, after my return from the East. The material, which was unlimited, was derived from patients of all nationalities who suffered from blackwater fever and malaria. The study of the disease was made on certain lines and the findings will be recorded in the various sections into which the work is divided.

No attempts will be made to discuss certain of the problems of this interesting disease which have been dealt with by previous workers, many of whom have made observations on cases of blackwater fever year after year in tropical and subtropical countries. 


\section{SECTION I.}

\section{ABNORMAL CHANGES FOUND IN THE BLOOD PLASMA, SERUM, AND RED BLOOD CORPUSCLES IN BLACKWATER FEVER.}

1. Jaundice-bile pigment. 2. Haemoglobinaemia. 3. Observations on the blood cells.

4. On the serum reaction for syphilis. 5. Parasites: (a) Spirochaetes; $(b)$ Malarial.

1. Jaundice. William Hunter (1908) writing on Jaundice says: "It is characterised by yellowish discoloration of the tissues with bile pigment," but he also refers to a condition known as "Urobilin jaundice" which he regards as a true jaundice, associated with urobilinuria, and due to the formation of urobilin from bilirubin in the intestine. There are others who regard jaundice as a pigmentation of the blood and tissues due to the presence of bile pigments alone, and do not include the pigmentation due to the presence of urobilin. There is little doubt, in my opinion, that if the definition of jaundice were strictly confined to the abnormal discoloration produced by the presence of bile pigments in the blood and tissues, much greater clinical accuracy would ensue, as many medical officers in charge of patients employ the term jaundice without any clear definition of its meaning, with the result that any "yellowish appearance" of the skin or conjunctiva is termed jaundice.

Jaundice was observed in 20 of my cases out of a total of 49 in which full records were made. In some of the negative cases a yellowish discoloration of the conjunctiva was noticed, somewhat similar to that which is so well known in patients suffering from pernicious anaemia, but there was no evidence of bile pigment in the blood serum. In the 20 positive cases the yellow discoloration was proved to be due to bile pigment in the blood plasma, while in many instances the jaundice was intense, and in 16 out of the 20 cases a fatal result ensued. In three of the fatal cases, these having died on the fifth and seventh day of the disease, jaundice developed at the onset of blackwater fever, but icterus was absent at autopsy. In some of the negative cases, jaundice was stated to be present on clinical evidence, but bile pigment could not be demonstrated. It will be seen by reference to the postmortem findings that the bile in the gall bladder was extremely thick and concentrated, especially in the cases which were jaundiced, and such samples of bile were found to be actively haemolytic for human or animal red cells, owing to the presence of a high percentage of bile salts. Concentrated bile occurred, however, apart from jaundice among the cases of blackwater fever.

The method which was adopted for testing the presence of bile pigment in the blood serum or plasma was as follows: Blood serum or plasma mixed with red cells, or free of the latter, was evaporated in a porcelain dish on a water bath to a dry sticky residue. Cold water was then rapidly passed over it, and all excess removed before fuming nitric acid was added with the usual precautions to the dried residue. If bile pigment was present a play of colours developed showing a definite green streak, which varied in intensity according to the amount of bile pigment present. The reaction, however, is quite distinctive and in my experience since Dr A. Wilkin drew attention to the value of rapidly 
washing the surface of the dried blood with cold water the test has been found to be accurate and perfectly easy to manipulate ${ }^{1}$.

Albert Plehn (1914), in his classification of blackwater fever into five groups, states that jaundice occurs in four out of the five. Arkwright and Lepper in their report on 16 cases of blackwater fever occurring in the Eastern Mediterranean state that jaundice of some degree was present in 15 cases. In eight instances it was slight; in six it was much more definite; and in one case it was intense. The blood serum gave a marked reaction for bile pigment in the severe case, and "in two or three other cases slight reactions were obtained, probably indicating bile pigment." Bile pigment was not found in the urine in any instance. There is no definite proof that true jaundice occurred in all their cases, as the nature of the pigment in the blood plasma was not determined. It is extremely important to have accurate data as to the nature of the pigment in this disease, and Arkwright and Lepper fully realise this fact as they doubt the wisdom of giving a decided opinion without such positive information. They emphasise that the liver is disordered and swollen in blackwater fever and the bile inspissated.

Phear (1920) has recorded recently some clinical notes on blackwater fever occurring in Macedonia, in which intense jaundice was present in 17 of the 40 fatal cases, while in 13 it was well marked. Throughout the literature of blackwater fever mild to intense jaundice is commonly referred to in the records of cases, but as far as can be ascertained from the data furnished, the diagnosis rests purely on clinical evidence. It is of course unnecessary to adopt any other means in cases of intense jaundice, but in those who show a "lemon tinging" of the conjunctiva an examination of the blood plasma, or serum, should be made so as to ascertain whether bile pigment is the cause of the abnormal pigmentation. The abnormal coloration of the urine in blackwater fever was found to be due in some of my cases to urobilin.

2. Haemoglobinaemia. Muir and Dunn (1915a) recognise three degrees of haemoglobinaemia, all of which lead to accumulations of iron in the kidneys: (a) a degree too slight to be detected directly (this is probably the case in pernicious anaemia), (b) a degree sufficient to enable the free haemoglobin to be recognised in the plasma; and (c) a degree sufficient to produce also haemoglobinuria. Corresponding to these three degrees of haemoglobinaemia there will be increasing amounts of haemosiderin in the kidneys.

The blood withdrawn from a vein in a case of blackwater fever may show evidence of haemolysis, varying from a deep red coloration of the plasma to a faint tinging. If the blood is withdrawn from a vein into a large test tube $(6 \times 1)$ with all reasonable precautions, and immediately sloped, the serum will separate rapidly at $37^{\circ} \mathrm{C}$., or at the temperature met with in the tropics, and the escape of haemoglobin from the red cells will not occur through a technical error, and thus give a false observation. At the end of one hour's incubation at $37^{\circ} \mathrm{C}$. the tube of blood is placed in the perpendicular position

1 The addition of a few drops of water at the end of the reaction will intensify a feeble result. 
in the ice safe. The evidence of haemoglobinaemia rapidly disappears from the blood, so that this phenomenon may be overlooked, unless the examination is made at the correct moment. The spectrum obtained is oxy- or methaemoglobin, or both may be present in the same sample of blood serum.

Arkwright and Lepper (1918) looked for evidence of haemoglobinaemia in ten of their cases, and obtained positive findings in four, while various workers on blackwater fever have shown previously that there is a haemoglobinaemia in this disease. Barratt and Yorke in 1909 brought forward evidence to show that the haemoglobinaemia preceded the haemoglobinuria, while from their investigations on piroplasmosis in dogs they showed that the haemoglobinaemia appears as soon as the blood plasma contains as much haemoglobin as is obtained from an amount of red cells equal to 0.5 per cent. by volume of the plasma. The percentage of haemoglobin in the urine is generally greater than that in the blood plasma.

Muir and McNee (1912) found from experiments conducted on animals with haemolytic immune sera that the amount of haemoglobin passed in the urine is small in relation to the degree of blood destruction. They refer to one instance in which 157 c.c. of dark brown urine were passed in $\mathbf{4 8}$ hours, but it contained an amount of haemoglobin corresponding only to 3 or 4 c.c. of blood.

3. Observations on the blood cells. Investigations on the total number of red cells per c.mm. and the percentage of haemoglobin were made in many cases of blackwater fever during the period of haemoglobinuria, and in the stage of intense anaemia which may persist when the haemoglobinuria has disappeared, but no estimation on blood volume was attempted. The degree of anaemia in this disease is very considerable, as would be expected, and is often of a rapidly progressive type.

The following case serves as a typical example of this progressive anaemia. Onset of blackwater fever on April 2nd, 1917. On the following day the disease was present with all its characteristic manifestations, and the red cells numbered 2,380,000 per c.mm. On April 4th, the haemoglobinuria was completely arrested, but the red cells numbered 1,900,000 per c.mm., and on the next day the urine again showed haemoglobinuria and the red cells totalled 824,000 per c.mm. Death occurred 48 hours later. At the autopsy the man was jaundiced and most of the internal viscera showed the effects of arterial thrombosis.

In six cases the red cells were counted a few hours previous to the death of the patients with the following results:

$\begin{array}{lllll}\text { 1. Case } 2 & \ldots & \ldots & 0,992,000 \\ \text { 2. Case } 3 & \ldots & \ldots & 1,330,000 \\ \text { 3. Case } 12 & \ldots & \ldots & 1,000,000 \\ \text { 4. Case } 18 & \ldots & \ldots & 0,900,000 \\ \text { 5. Case } 24 & \ldots & \ldots & 0,824,000 \\ \text { 6. Case 25 } & \ldots & \ldots & 1,048,000\end{array}$

Polychromatophilia and punctate basophilia occurred in many instances, and it has been suggested that quinine is contra indicated in such cases, but my observations do not confirm this view. The total number of leucocytes varied from 34,000 to 1600 per c.mm. without any adequate explanation for such marked variations in cases of equal severity. 
Hannemann (1918a) records the fact that an intense leucocytosis and increase of polymorphs may occur with the rigor, while subsequently there is a leucopenia and an increase of large hyaline cells.

Arkwright and Lepper (1918) refer to the extreme anaemia which may occur after 24 to 48 hours of blackwater fever, and compare the general appearance of the patient to the anaemia following severe haemorrhage. In addition to the severe blood destruction which occurs, haemorrhages into the serous sacs, or externally, may still further drain the system of its normal blood content. Many cases succumb to the severe anaemia which necessarily follows a severe attack of blackwater fever, when the tissues may show the most profound changes including fatty degeneration of the myo-cardium.

Albert Plehn (1914) in his classification of blackwater fever considers that the anaemia on the third, fourth, or fifth day is the most dangerous complication.

Muir and McNee (1912) found from their experiment on animals injected with haemolytic sera that the rate of regeneration of red corpuscles was very rapid. The mean of all their experiments taken together gives the most rapid daily increase to be not much less than 500,000 corpuscles per c.mm.

Red cell fragility. Numerous experiments were made on the fragility of the red cells of patients in the acute and convalescent periods of blackwater fever. Whole blood was employed, or washed red cells, or both, but the fragility remained within the limits of normal blood in every instance.

Bijon (1915) found a diminished resistance of the red cells to various strengths of salt solutions in cases of blackwater fever, and believed that he had found an autolysin in the blood.

Auto- and iso-haemolysis. The serum and red cells obtained from the same case, and other cases of blackwater fever, were tested for the presence of haemolysins and agglutinins, but negative results occurred in every instance with the patient's own blood (auto), while there was no evidence that sera obtained from cases of blackwater fever had any special affinity for normal human red cells, or that the red cells from cases of blackwater fever were susceptible to the action of fresh human sera.

Fletcher (1913), in the Federated Malay States, tested the serum and red cells from three cases of blackwater fever, but was unable to demonstrate haemolysins or agglutinins for the autogenous red cells, or for other samples of red cells, and was unable to lyse the red cells from the blackwater fever cases with normal sera.

Porak (1918) examined the serum and a watery extract of the organs both fresh, and dried at $56^{\circ} \mathrm{C}$., obtained from one case of blackwater fever, on the patient's red cells and healthy cells, but was unable to obtain any evidence of haemolysis. The microscopical changes found in the viscera in this case, however, were not sufficient to warrant a positive result.

In 1909, de Raadt $(1917,2)$ put forward the suggestion that blackwater fever is due to the formation of certain immune substances which have both a haemolytic and a parasiticidal action, together with an excess of complement in the circulating blood. He believed that the actual onset of blackwater fever depends on the amount of complement present which is free to act with the immune substances formed. Further, he suggested that chill, excessive exercise, and quinine are able to stimulate this increased formation of com- 
plement. He conducted some experiments with five healthy Javanese and 15 who were suffering from chronic malaria. In four of the former the haemolytic activity of the serum was unaltered, but increased in one case, while in eight of the latter it was found to be raised from 50 to 100 per cent. In his opinion, it is for this reason that persons suffering from chronic malaria who take quinine when they visit blackwater fever areas are in danger of contracting the disease. The views advanced by de Raadt to explain the causation of blackwater fever however are not capable of experimental proof, while he fails to supply adequate reasons for these various suggestions.

Frieberger and Hartoch consider that intravenous injection of strong hypertonic saline reduces the amount of complement in the blood. De Raadt adopted this method of "treatment" for three Javanese suffering from chronic malaria to whom he gave intravenously 80 c.c. of a 10 per cent. solution of sodium chloride, but failed to observe a reduction in the complement in the blood.

4. On the serum reaction for syphilis. It has been suggested that blackwater fever is dependent upon syphilis just as it is known to be the common aetiological factor in paroxysmal haemoglobinuria, although Barratt and Yorke (1909) considered that venereal disease does not predispose to blackwater fever or influence its course when present. Napier (1913) writing in The Indian Medical Gazette, in 1913, favoured the view that syphilis was the cause of blackwater fever, further he suggested that the Wassermann reaction should be made in all cases of blackwater fever and if the reaction was positive, salvarsan should be administered. These suggestions made by Napier are exceptionally unpracticable more especially in a disease which occurs under such unfavourable surroundings as blackwater fever, while he brought forward no positive evidence that blackwater fever is dependent on syphilis. The blood serum was tested for syphilis in 25 of my cases, but the results were negative except in the case of a Serb, and an Indian, both of whom were known to have had the disease, while there was no reason to suppose in either instance that syphilis was definitely related to the acute illness. Arkwright and Lepper refer to the examination of the blood in three cases by Capt. M. Douglas, R.A.M.C., with negative results. These examinations were made one and a half, and one month, respectively, after the onset of blackwater fever.

Microscopical examination of the tissues in blackwater fever has failed to reveal any evidence of syphilis. There is, therefore, nothing to suggest that blackwater fever is either related to, or dependent, upon syphilis.

5. Parasites in the blood. (a) Spirochaetes, (b) Malarial.

Spirochaetes. The blood in cases of blackwater fever was examined at the height of the paroxysm and subsequently, by the following methods, (1) dark ground, (2) Fontana Tribondeau, (3) Levaditi, (4) Giemsa, and (5) Leishman for parasites other than malarial, but without success. The blood was also lysed and then centrifugalised and film preparations made of the débris, but no spirochaetes were seen by this elaborated technique.

Malarial parasites. In the hundred cases of blackwater fever which have been investigated a malarial history was obtained in everv instance, while

Journ. of Hyg. xIx 
without exception the infection had been contracted during the European war in the Balkans 1915-1918.

Film preparations ${ }^{1}$ of the blood in immediate relation to the paroxysm were made in only 40 instances out of the 100 cases examined, and of these in 42 per cent. malarial parasites were demonstrated of which 60 per cent. were malignant rings or crescents. The interval between the attack of blackwater fever and the last attack of malaria is important, but no reliable inference can be drawn from these findings, because a negative history of malaria was of little or no value among our troops in the Balkans, as in many instances men who had never been "sick" and flatly denied the knowledge of any illness resembling malaria, yet, proof positive evidence of this disease was obtained. In 1917, various investigations were made under my direction on the Balkan Fronts for the purpose of detecting malarial carriers, and unsuspected cases of malaria, of which certain examples will be quoted: 80 men, who gave no previous history of any illness in the Balkans, were examined for the presence of malarial parasites, with the result that 33.6 per cent. were found to be positive (B.T. 24 and M.T. 3). During the winter of 1916-17, 2836 men were examined on the Struma Front and no less than 835 were found to be positive malarial carriers. The clinical diagnosis of sand fly fever, trench fever, and P.U.O. (pyrexia-unknown origin) gave every chance for error to occur. In one instance with which I am acquainted, the diagnosis of sand fly fever was made in some 20 odd cases by an "enthusiast" who was anxious to show the value of active anti-malarial measures; but the Plasmodium vivax was found in the peripheral blood in 80 per cent. of these cases. The small percentage of blood examinations made during the paroxysmal period of blackwater fever is unfortunate because so many competent observers hold that with the blood destruction the parasites disappear also. Stephens (1913) stated "in blackwater fever it is the general experience that parasites when found rapidly disappear" and it is for this reason that the importance of the presence of pigmented leucocytes and melanin has been considered so as to ascertain the relationship between malaria and blackwater fever.

Seyfarth (1918) found that all his cases (Balkans-European War) had had many attacks of malaria, while malarial parasites were present in the blood in nine out of the ten cases, of which eight were malignant malaria and five were fatal. The men also received most insufficient and irregular treatment with quinine for a considerable period. They were underfed and overworked. Stephens, in his article on blackwater fever in Allbutt's System of Medicine, showed from an examination of the blood in 95 cases of blackwater fever, that the demonstration of malarial parasites in the blood in this disease depends almost entirely upon the time when the blood examination is made, as illustrated by the following figures:

(1) Blood examination. Day before onset of haemoglobinuria. Parasites present in $95 \cdot 6$ per cent.

(2) On the day of the haemoglobinuria $61 \cdot 9$ per cent.

(3) On the day after the haemoglobinuria $17 \cdot 1$ per cent.

1 Thick films were employed in the minority of cases. 
The results of the figures arrived at by Stephens have led to the view that the severe blood destruction is the cause of this reduced percentage of positive findings, but for this reason one case in my series is worthy of consideration. The haemolysis was intense, the blood serum was deep red, but the blood was shown to be very heavily infected with malignant ring parasites. The patient died within 24 hours from the onset of the acute illness, and the tissues showed a very heavy infection with parasites both intracellular and free. Another case with less pronounced changes in the blood and tissues was also met with. These two cases prove that in spite of very active blood destruction at the time when the blood examination is made, yet a heavy malarial infection of the red cells may persist. It is possible that other factors in addition to the presence of a haemolysin in the blood may explain the reduction of positive findings to which Stephens has drawn attention. Dudgeon (1919) has shown that when a patient receives an intramuscular injection of quinine complete lysis of red cells occurs in the affected muscles, but the parasites may still be seen in large numbers lying among the débris of red cells. Dr Nakayawa confirmed the observations made by Stephens, as he found malarial parasites in 85 per cent. of cases prior to the onset of blackwater fever (M.T. 14, B.T. 2 and Q.M. 1), but only 12.8 per cent. were positive one or two days after the onset. Hatori (1915) examined 26 cases and found parasites in $96 \cdot 3$ per cent. before the attack of blackwater fever commenced ${ }^{1}$.

\section{SECTION II.}

\section{THE TISSUE CHANGES IN BLACKWATER FEVER.}

The heart. In 17 cases the condition of the heart muscle was recorded in detail. In the cases which ran an acute course, it was flabby, and there was intense pallor of the muscle substance with sub-pericardial haemorrhages, and the papillary muscles showed well marked mottling. There was dilatation of the heart, especially of the right side.

On microscopical examination, fatty degeneration was present throughout the muscle substance, or in localised areas. The heart was examined for fatty degeneration ${ }^{2}$ in 17 cases of blackwater fever, with the result that diffuse fatty degeneration was demonstrated on three occasions, similar to the severe type of fatty degeneration of the heart muscle which has been recorded in acute diphtheritic toxaemia by Dudgeon (1906), while localised areas of fatty degeneration occurred in five cases. It was not possible to demonstrate fatty degeneration of the heart muscle in the nine remaining cases of blackwater fever. In one case in which diffuse fatty degeneration had occurred, and one

1 Leishman, in 1912, drew attention to certain bodies which he found in the endothelial cells of the visceral blood or lymph vessels, and which he considered might be parasitic (Chlamydozoa). He found these bodies in three cases of blackwater fever. See Leishman, W. (1912). Cell-inclusions in the blood in Blackwater Fever. Journ. Roy. Army Med. Corps. Vols. xvinI and xix.

2 Scharlach R. staining was used throughout for these investigations. 
of less severity, the parasites of pernicious malaria were present in the blood stream, while in the remaining cases, melanin was demonstrated in one or more of the viscera. Dudgeon and Clarke (1919) have shown in pernicious malaria that fatty degeneration of the cardiac muscle occurred in 23 out of a total of 45 cases examined, while in five instances diffuse fatty degeneration was met with. It might be argued, therefore, that this degeneration of the cardiac muscle was malarial in origin, quite apart from the toxic action induced on the tissues in blackwater fever. Fatty degeneration of the cardiac muscle in blackwater fever is a pathological process which might be expected to occur because it is a well recognised condition in certain other diseases associated with severe blood destruction, as pernicious anaemia, and streptococcal septicaemia.

Marked perinuclear granularity occurred with and without the presence of fatty degeneration. Sub-pericardial haemorrhages were met with on three occasions. In one case there was diffuse fatty degeneration of the cardiac muscle, and a large intramuscular haemorrhage associated with a wide tract of necrosis; a similar condition occurred in the other viscera in this case owing to widespread vascular changes.

Hannemann (1918a) considers that the haemorrhagic state may be due to quinine derivatives cinchonine, chinicine and cinchonicine acting partly locally on the vasomotor system and partly centrally. This view however is obviously incorrect as the haemorrhagic condition in blackwater fever has no relationship to the quinine intake, and, further, in animals which have received experimentally massive doses of quinine, a haemorrhagic state is not induced.

It has been suggested that the changes present in blackwater fever are dependent upon anaphylaxis and Porak ${ }^{1}$ has compared blackwater fever to this condition. There is no evidence in my opinion for this suggestion as an explanation of the pathology of this disease, while the tissue changes in blackwater fever are absolutely distinct from what is met with in anaphylaxis. A typical example of death from anaphylaxis is detailed below together with the microscopical findings which certainly confirms my belief in the absence of any similarity between the two conditions. An officer was slightly wounded on the Doiran-Vardar Front, and was given 500 units of anti-tetanic serum hypodermically. Within ten minutes of the injection, he suffered from dyspnoea which became rapidly worse and death occurred within 35 minutes of the inoculation. At the autopsy, sub-pleural haemorrhages were present, and marked congestion of the alveolar walls, and haemorrhages into the lung tissue and bronchi. There was acute emphysema, but no inflammatory reaction. The thymus was enlarged, and showed scattered haemorrhages,

1 Cleland, in 1909, had suggested that blackwater fever was the resultant condition, the evidence of anaphylaxis to (dead) Plasmodium proteid. See Cleland, J. B. (15. x. 1909). Is Blackwater Fever the expression of anaphylaxis to a Malarial Plasmodium ? Journ. Tropic. Med. and Hygiene. 
and the spleen also, but there was no evidence of malaria. There were no changes detected in the liver, kidneys, or other tissues. Another case of death from anaphylaxis was similarly investigated. This patient had malaria, but the findings were not sufficient to suggest blackwater fever. The only phenomenon which is common to both conditions is the haemorrhagic state, but this occurs from numerous causes.

No definite relationship was established between the presence and degree of fatty degeneration of the cardiac muscle in these cases of blackwater fever and the rapidity of the disease from the time of onset of symptoms to the death of the patient, although in two out of the three cases which showed marked fatty degeneration death occurred on the third and fifth days respectively from the time of onset of symptoms. It is obvious, however, that this degenerative change of the cardiac muscle in blackwater fever is of the utmost importance more especially when we consider the severe blood destruction and other effects on the tissues which occur. Full attention should be given to these findings by medical officers in charge of cases of blackwater fever ${ }^{1}$.

The adrenal glands. Dudgeon and Clarke in the communication referred to elsewhere state that in the examination of the adrenal glands in 35 cases of pernicious malaria the most constant lesion was the reduction of the fat lipoid content in the cortical layers. In no less than 30 cases such reduction was noted, while in many instances the loss was considerable.

In blackwater fever similar results have been observed. A reduction of the fat lipoid content was one of the commonest pathological changes met with in this disease as in pernicious malaria, while in a few instances no chromaffine was detected in the medulla of the glands by the chromic acid test. It was observed that when the fat lipoid in the superficial layers of the adrenal cortex was reduced to a minimum as shown by the fat stains especially Scharlach R., it might be present as fine scattered granules in the deepest layers. Fatty change in the cells of the medulla of both adrenals was met with on one occasion. This patient had recently recovered from active pernicious malaria with numerous ring parasites in the circulating blood, and this was his third attack of blackwater fever within a period of three months. In some cases congestion of blood vessels, haemorrhages, masses of agglutinated red cells in the vessels, and necrosis of gland tissue were recorded.

Paisseau and Lemaire (1916) considered these changes to be of the utmost importance in pernicious malaria. They grouped the pathological findings and the clinical phenomena under the term "acute suprarenal insufficiency."

In one instance of rapidly fatal blackwater fever "colloid-like bodies" which varied considerably in size were numerous in the medulla of the glands.

\footnotetext{
1 Castellani refers to the condition of the heart in blackwater fever as follows: "The heart's action should be carefully watched and may' require support," but he does not describe the pathological state of the Cardial muscle in this disease. See Castellani, A. and Chalmers, A. (1919). Manual of Tropical Medicine. London, Ballière, Tindall and Cox.
} 
Spleen. The spleen was enlarged in every case of blackwater fever in this series. In some instances the enlargement was very considerable. In the very acute cases the colour varied from dark red, or chocolate, to almost black, similar to the appearances which the spleen may present in animals which have succumbed to a haemolysin. Recent or chronic perisplenitis was present in all cases. Prominent white Malpighian corpuscles were of common occurrence, while a large, dark chocolate coloured spleen dotted all over with prominent large white Malpighian corpuscles gave a striking appearance which this organ frequently presented in blackwater fever. The microscopical changes were very numerous, but many known to occur in malaria were met with in blackwater fever, which could be explained by the fact that every case had suffered recently or within the last few years from one or more attacks of malaria.

The result of the microscopical examination of the spleen in blackwater fever varied in different cases, according to whether the patient died in the acute stage of the disease, or subsequently from grave anaemia, while the microscopical appearances were not necessarily similar among the cases in either period. The following changes which occurred will be referred to:

Localised patches of necrosis of the splenic stroma; less frequently this condition occurred as a widespread lesion. The sinuses were distended with blood and marked congestion of their walls was observed. Agglutination of red cells in the sinuses occurred and active phagocytosis of red blood corpuscles by the endothelial cells lining the walls or free in the sinuses. The phagocytic reaction when well marked gave a striking appearance to sections of the organ, while evidence of haemolysis in the blood vessels and splenic sinuses still further intensified the picture. Endothelial cell activity was a marked phenomenon in some of the spleens and also the formation of small giant cells. This endothelial cell activity with enlargement of the splenic sinuses developed at the expense of the lymphoid tissue. Thrombosis in the large vessels was seen in two cases with infarction of the splenic tissue. The staining of the red cells in the splenic sinuses by a double stain, such as Giemsa or Leishman, showed varying colour effects from the normal red to brown, grey, and shades of blue. This polychromatophilia was very pronounced in some instances. Polymorphs were found to be numerous in the sinuses in a few cases.

Melanin. Free-iron. Melanin was present in the sinus cells, or free, and also a true iron-free pigment, while in some cases a very marked free-iron reaction in the splenic stroma occurred. The free-iron reaction was demonstrated in the tissues as small, medium, or large granules, or as a diffuse blue staining of the tissues or individual cells. Free-iron was demonstrated occasionally in the Malpighian corpuscles. Melanin was'found to give a free-iron reaction by "unmasking," while in some instances the apparent melanin granules were found to give a free-iron reaction; similar observations were made on the melanin granules in the liver. This, however, was not observed in malaria.

The Malpighian corpuscles. It has already been stated that the large size and prominence of these bodies is frequently one of the striking features at 
an autopsy in cases of blackwater fever ${ }^{1}$. The enlargement is due to active endothelial cell proliferation with partial necrosis of many of the enlarged cells, while the normal lymphoid tissue content is reduced to a minimum. Large coarse free-iron granules were demonstrated in these bodies occasionally, while melanin was absent or present in very small amount. Dudgeon and Clarke described similar changes in the Malpighian corpuscles in malaria. They state as follows: "Endothelial cell proliferation in the central areas of these bodies is not infrequent, while in some cases these endothelial cells have undergone partial or complete necrosis."

The gall bladder. In several cases detailed observations were made on the condition of the gall bladder and of its contents, and the bile passages. The bile in the gall bladder was very thick-in some cases almost solid and of a deep green or orange colour, while the gall bladder in some instances was distended and the bile passages in the liver blocked, with thick tenacious bile. Samples of such bile were boiled to remove bacteria and extraneous substances and the haemolytic action on human red cells was tested, and controlled against a 2 per cent. solution of bile salt in saline.

Dudgeon (1918) has shown that human bile is very variable in its haemolytic action, and while some samples are very inactive, others may be equal to, or even greater than 2 per cent. bile salt in saline. Further he showed that this haemolytic action is intensified in the presence of calcium, but rendered inert by the addition of sufficient blood serum. Concentrated thick bile, which is actively haemolytic, owing to a high percentage of bile salts, is found in the gall bladder in blackwater fever and many other conditions. In several cases of blackwater fever I have found that the concentrated bile was as actively haemolytic, or even more so, than 2 per cent. bile salt. This occurs in obstructive jaundice, although jaundice was not present in each case referred to here at the time of the autopsy, in spite of the presence of inspissated bile in the gall bladder and bile passages. Arkwright and Lepper refer to the marked inspissation of the bile in the gall bladder in their cases of blackwater fever, and compared it to porridge, while in one case with considerable jaundice the bile capillaries were blocked with inspissated bile, and dilation of bile capillaries was also seen.

The liver. Numerous changes occur in the liver in blackwater fever, but enlargement and foci of necrosis were met with in every instance. The colour of the liver varied considerably in the large number of cases investigated. In some instances it was dark grey, or light orange, but most frequently a yellowish brown colour. Congestion was of common occurrence, while in several instances haemorrhages beneath the capsule and in the liver tissue occurred, which varied in size from a pin's head to an obvious splash of blood in the liver tissue. The bile capillaries were distended with thick bile such as occurred in the gall bladder.

1 The prominence of the Malpighian corpuscles may suggest scattered tubercles to the casual observer. 


\section{Microscopical Examination.}

The microscopical appearance of the liver in blackwater fever may be relatively slight, but usually marked or intense degenerative and reactionary changes occur similar in many respects to those which accompany certain toxic conditions which act upon the liver cells. Foci of central necrosis of the hepatic cells are among the commonest lesions of blackwater fever, while in some instances wide tracts of liver tissue are necrosed. The haemorrhagic areas which have been referred to may merge into the necrotic tissue, as is seen in an exaggerated form in acute yellow atrophy of the liver. Fatty change in the liver cells occurs in and around these foci of central necrosis, while an intense polymorph reaction may also be met with. The polymorphs are intermixed with necrosed liver cells and the nuclear remnants of the hepatic cells. There may be an intense free-iron reaction in the liver cells, either in the central or peripheral areas, or both, or the liver cells may be filled with a yellow iron-free pigment. The sinuses may be widely dilated and agglutination of red blood corpuscles may be observed. Melanin is found free or in the sinus cells, while in some instances free-iron granules or a diffuse iron staining of the sinus cells together with the melanin particles may occur. Numerous mononuclear cells may be met with in the dilated liver sinuses. The liver cells may contain bile pigment, and the bile passages may be found widely dilated and apparently blocked with bile.

Pancreas. The pathological changes met with in the pancreas were common to those found in the tissues which have been already referred to. No instance of fat necrosis or haemorrhagic pancreatitis occurred, although haemorrhages and congestion of blood vessels were of common occurrence. Marked degeneration of the islets of Langerhans was noted on two occasions. The cells were swollen, distorted, and showed nuclear changes, and in one instance sugar was present in the urine, and amounted to $0 \cdot 16$ per cent. in the blood.

The kidneys. These organs were often much enlarged, and varied in colour from a deep purple, or deep chocolate, to lighter shades according to the period of the disease in which the fatal result ensued, and whether active blood destruction was in progress. It is obvious, that the post-mortem findings are largely dependent upon the haemolytic factor. Haemorrhages were present in some cases and intense engorgement of the cortex and medulla, while in some instances the pyramids were a deep purple colour and the cortical markings were not recognisable. The microscopical findings varied in different cases, and for the reasons referred to above. When death occurred during the acute stage of the disease the renal tubules were filled with blood serum, granular débris, and agglutinated red cells which were especially well demonstrated in the convoluted tubules. The individual granules in the granular débris may reach a large size and the débris is found in the cells of the tubules and obstructing the lumina, more especially the convoluted and more highly specialised. This granular matter may be shown to contain 
traces of free-iron or iron in large quantities. Warrington Yorke (1911) has shown in the haemoglobinaemia due to piroplasmosis canis, that large granules occur in the epithelium of the convoluted tubules of the kidneys, and as already stated it is especially in the epithelial cells of the convoluted tubules that the iron granules are found. The epithelial cells of the tubules-more especially the convoluted-may show all stages of degeneration. The cells may be large, swollen, and vacuolated, and the nuclei may have disappeared, or the cells may be lying free in the lumen of the tubules, or may be collected together to form renal casts, but fatty degeneration was not as frequently demonstrated as might be expected. No case was observed in which advanced fatty degeneration of the renal epithelium had occurred. Large tracts of necrosis of the renal tubules were met with in some instances. All grades of congestion of the glomeruli occurred, from a slight to a very intense form, while a similar variation was observed in the blood vessels. Pigment was present in the glomeruli and also in the blood vessels. The endothelial cells of the glomerular tufts were shed in some cases in which death had occurred during the acute stages of the disease, and blood débris was present in the capsules, while the cells covering the capsular walls suffered in a similar manner. Complete blocking of the renal vessels occurred on one occasion, while acute degenerative changes in the muscular coat of the blood vessels was also met with. Acute inflammatory changes in the interstitial tissue did not occur in uncomplicated cases of blackwater fever. The kidneys were examined in a few cases which had suffered from blackwater fever at a previous period, but who died from some other illness. The interval between the attack of blackwater fever and the period when the kidneys were examined varied from a few weeks to some months. In no instance was any microscopical evidence of chronic nephritis found in the examination of the kidneys in these cases. These findings confirm the results obtained by the ordinary methods of urinary examination. Barratt and Warrington Yorke (1909) had arrived previously at a similar conclusion. No albuminuria of renal origin followed the attacks of blackwater fever coming under their notice, and judging from the cases recorded from the literature, blackwater fever is not a cause of nephritis.

Lungs. Sub-pleural haemorrhages were met with in a few instances and formed part of the haemorrhagic state which may occur in blackwater fever. Oedema of the lungs was common, while haemorrhages into the alveoli and considerable congestion of the alveolar walls were recorded on many occasions, and also haemorrhages into the lumen of the bronchi. In some instances the pulmonary haemorrhages were widespread and occurred in conjunction with areas of pulmonary collapse and oedema. Thrombosis or embolism of the pulmonary artery produced a fatal termination in two cases. In three instances the alveolar walls were very congested and the red cells contained ring and dot parasites of malignant malaria associated with blackwater fever. 
Thyroid gland. In a few instances the thyroid gland was examined microscopically. Considerable diminution in the colloid content of the thyroid vesicles was demonstrated, and in one instance active multiplication of the cells lining the vesicles had occurred.

Skin. Sections of the skin obtained from various parts of the body were examined microscopically. Pigmentation of the deepest layer of the epidermis was noted on a few occasions, and mononuclear cells containing yellow pigment granules were demonstrated in the corium, but the pigment found in both situations failed to give the free-iron reaction. There was no evidence of acute or perivascular inflammation present.

Spirochaetes. The spleen, kidneys, liver, bone marrow, adrenals and brain were examined by the original method of Levaditi, or one of its modifications for spirochaetes, but a negative result was obtained in every instance.

Film preparations of the tissue juices made and stained by the methods of Levaditi, Fontana Tribondeau, and Giemsa yielded the same negative result.

\section{On the Presence of Free-Iron.}

It has been shown that the presence of free-iron in the tissues is one of the most characteristic changes in blackwater fever. It is present either as the finest granules or as large coarse blocks of iron and is especially found in the spleen, kidneys and liver. In some instances, cells, in the liver sinuses especially, may be shown to be free from granules, but to stain a diffuse blue colour with the stains for free-iron. Apparent melanin granules in the liver and elsewhere may give a definite free-iron reaction in blackwater fever as if the melanin was "split" during the haemolytic process. The amount of free-iron in the tissues varies very considerably in different cases, and certainly the most intense reaction was found in two cases which had been transfused for severe anaemia.

Muir and McNee believe from their experiments with haemolytic immune sera that the intensity of the iron reaction is not an index of the degree of the blood destruction. They consider, and my results on the tissues of blackwater fever cases confirm this, that the rapidity of blood destruction with resulting haemoglobinaemia and haemoglobinuria is the important factor in the intensity of the iron reaction.

Muir and Dunn $(1915 b)$ in their experiments on haemolytic anaemia in rabbits found that the excess of iron stored in the organs has been largely absorbed by the time regeneration has occurred and they believe it has been utilised in the blood regeneration. The absorption of iron was most complete from the liver cells.

These investigators $(1915 a)$ had demonstrated in a previous paper that in acute haemolytic anaemia, attended with destruction of more than half of the blood within three days, nearly all the iron from the destroyed haemoglobin is deposited in the spleen, liver and kidneys. A certain amount of 
iron escapes in the urine during the haemoglobinuria, and the amount deposited in the kidneys is roughly proportional to this.

The Injection of "Malaria Melanin" into Animals.

The spleens obtained from malarial cases were cut into fragments, crushed and minced. The thick juice obtained was found to contain an abundance of melanin which was washed in saline on several occasions, and then injected into rabbits and guinea pigs intraperitoneally. No abnormal results were obtained in any of the inoculated animals. Inoculation experiments were made also with dried splenic powder containing an abundance of melanin, but no ill effects developed in the inoculated animals.

\section{SECTION III.}

\section{ON THE EXTRACTION OF THE URINE AND TISSUES IN BLACKWATER FEVER FOR THE PRESENCE OF HAEMOLYTIC SUBSTANCES.}

These experiments were undertaken so as to ascertain whether haemolytic substances were present in the tissues, and whether they were excreted in the urine in cases of blackwater fever.

\section{Tissue Extracts.}

Methods employed. Tissues were minced, and dried with a current of hot air, while alcohol was freely added to assist in the drying process. The dried residue was ground to a fine powder, weighed, and divided into equal portions, to one of which alcohol was added and to the other acetone, and then incubated at $37^{\circ} \mathrm{C}$. for 24 hours, but in some cases the extraction with alcohol and acetone was continued for seven days. No advantage was gained by this prolonged method. The extracts were then stored on ice for a few days, filtered, and the filtrate was evaporated to dryness with hot air, and then taken up in 2-5 c.c. of alcohol or acetone, as required. Experiments were conducted also to ascertain whether "haemolytic bodies" could be extracted from the urine in blackwater fever. The following plan which was adhered to throughout except in certain minor details was as follows: In most cases the results were obtained by extracting fresh samples of urine, but in some instances 24 hour specimens were employed. Care was taken to include the deposit which is generally so bulky during the acute stages of blackwater fever. Amounts varying from 50-200 c.c. were employed for these investigations. Each sample was dried in an oven so arranged as to permit a continuous supply of hot air to be driven across the specimen until it was apparently dried, or until it became of a gluey consistency, when further drying produced no greater effect. Absolute alcohol was frequently added and well mixed with the débris during the drying process.

These extracts were diluted with saline and tested with human, sheep or 
rabbit red cells. In all experiments a final dilution of 1 in 20 of the red cells in the saline extract was obtained.

The results were recorded after two hours' incubation at $37^{\circ} \mathrm{C}$., and one hour on ice.

Results. In 11 specimens of urine out of 27 no haemolysis occurred with the alcohol or acetone extracts in saline, while with 16 extracts haemolysis was present in dilutions of 1 in 10 or greater, and on eight occasions it occurred with both the alcohol and acetone extracts. The three most potent extracts acted in dilutions of 1 in 33,1 in 40 , and 1 in 50 respectively and will be referred to subsequently.

A short résumé is given of those cases in which the organ extracts were proved to have active haemolytic properties.

Case 21 : Private P. Admitted to hospital with blackwater fever April 19th, 1918. Died April 24th, 1918. Urine was clear of blood pigment before death. Patient had very marked anaemia, jaundice, and a haemorrhagic eruption. All the tissue changes were very marked on microscopical examination. Patient had taken 80 grains of quinine between the 13th and 18th days of April-that is in the same month as the blackwater fever developed. In 150 c.c. of urine passed at the height of the attack, $0.0135 \mathrm{grm}$. of quinine alkaloid was extracted, while at the final stage just before death, $0.067 \mathrm{grm}$. was found in 145 c.c. of urine. The following results were obtained by extracting the urine and kidneys with alcohol and acetone:

$\begin{array}{llc} & \text { Extract } & \begin{array}{c}\text { Haemolytic end } \\ \text { point }\end{array} \\ \text { Urine } & \text { Alcohol } & 1 \text { in } 20 \\ & \text { Acetone } & 1 \text { in } 50 \\ \text { Kidney } & \text { Alcohol } & 1 \text { in } 200 \\ & \text { Acetone } & 1 \text { in } 300\end{array}$

75 c.c. of urine were used for this examination, while 5 grms. of dried kidney tissue were employed for the alcohol and acetone extractions, and each extract was taken up in 5 c.c. of alcohol and acetone respectively.

Case 23: Private E. Admitted to hospital on April 20th, 1918, suffering from blackwater fever, and died two days later. Patient had very severe anaemia, marked jaundice, and suppression of urine. The tissues showed microscopically such changes as are found in the very severe cases of blackwater fever. There is no record of the amount of quinine taken within a week of the onset of the acute symptoms, although it was known that he had had quinine for some time during his residence in the Balkans.

$\begin{array}{llc} & \text { Extract } & \begin{array}{c}\text { Haemolytic end } \\ \text { point }\end{array} \\ \text { Urine } & \text { Alcohol } & 1 \text { in } 20 \\ & \text { Acetone } & 1 \text { in } 10 \\ \text { Kidney } & \text { Alcohol } & 1 \text { in } 100 \\ & \text { Acetone } & 1 \text { in } 500\end{array}$

50 c.c. of urine were used in these experiments, and the dried residue was taken up in 5 c.c. of alcohol and acetone. $15 \cdot 2$ grms. of dried kidney tissue 
were used, of which 7.6 grms. were employed for the alcoholic extract and the same quantity for the acetone. The final residue was taken up in 5 c.c. of alcohol and acetone.

Case 38: Private H. was admitted to hospital with blackwater fever on March 24th, 1918, in extremis, and died the following day. He had very severe jaundice with bile pigment in the urine. The abnormal condition of the urine was such as is found in the most severe cases, and the microscopical changes in the tissues were very advanced.

$\begin{array}{ccc} & & \text { Haemolytic end } \\ \text { Exine } & \text { Alcohol } & 1 \text { in } 10 \\ \text { No acetone extract was prepared. } \\ \text { Kidney } & \text { Alcohol } & 1 \text { in } 30 \\ & \text { Acetone } & 1 \text { in } 100\end{array}$

90 c.c. of urine were used for extraction, and the residue was taken up in 6 c.c. of alcohol only. 10 grms. of dried kidneys were used for the extraction; $5 \mathrm{grms}$. in alcohol and the same amount in acetone, while the final products were taken up in 2 c.c. of alcohol and acetone.

Case 48: Gunner S. was admitted to hospital with blackwater fever on April 2nd, 1917, and died seven days later. The urine was free from blood and blood pigments 24 hours before death. There was grave anaemia, marked jaundice, and the microscopical changes in the tissues were very advanced. He had taken 30 grains of quinine during a period of 72 hours before admission to hospital with blackwater fever. The extraction of 200 c.c. of urine showed: $0.010 \mathrm{grm}$. of quinine alkaloid.

\begin{tabular}{llc}
\multirow{4}{*}{ Urine } & Extract & $\begin{array}{c}\text { Haemolytic end } \\
\text { point }\end{array}$ \\
& Alcohol & 1 in 10 \\
Kidney & Acetone & 1 in 10 \\
& Alcohol & 1 in 10 \\
Spleen & Acetone & 1 in 40 \\
& Alcohol & 1 in 10 \\
& Acetone & 1 in 200
\end{tabular}

100 c.c. of urine were used for the drying experiments, and equal portions of the residue were taken up in 10 c.c. of alcohol and acetone. 30 grms. of dried spleen, and 18 grms. of dried kidneys, were divided equally for the extraction with alcohol and acetone. The final extracts were taken up in 10 c.c. of alcohol and acetone respectively.

Case 31: Lance-Corporal K. Admitted to hospital in September, 1918, with blackwater fever (second attack). There was slight jaundice, the urinary changes were very severe, but the patient made a complete recovery. No quinine had been given this year previous to the attack of blackwater fever.

$\begin{array}{ccc} & & \text { Haemolytic end } \\ \text { Urine } & \text { Extract } & \text { point } \\ & \text { Alcohol } & 1 \text { in } 40 \\ & \text { Acetone } & 1 \text { in } 20\end{array}$


75 c.c. of the urine obtained during the acute stages of the disease were employed for the extraction, and $2 \cdot 25$ grms. of the dried residue were taken up in 10 c.c. of alcohol and acetone respectively.

Case 60: Private S. Admitted to hospital, April 19th, 1918, with very acute symptoms of blackwater fever, but made a complete recovery.

$\begin{array}{clc} & \text { Extract } & \begin{array}{c}\text { Haemolytic end } \\ \text { point }\end{array} \\ \text { Urine. Fresh sample } & \text { Alcohol } & 1 \text { in } 33 \\ & \text { Acetone } & 1 \text { in } 10 \\ 24 \text { hours' sample } & \text { Alcohol } & 1 \text { in } 25 \\ & \text { Acetone } & 1 \text { in } 10\end{array}$

75 c.c. of fresh urine and a 24 hours' sample were evaporated and dried, and the residue was taken up in 5 c.c. of alcohol and acetone respectively.

CoNTrol CASES. Many control cases of malaria and other infections were employed for comparison with the findings obtained in blackwater fever. In no instance, however, was an active extract obtained. The following cases which give the average findings will be cited briefly.

Case 1. Acute streptococcus streptocaemia. 19 grms. of dried liver were extracted with 190 c.c. of absolute alcohol. The final extract was taken up in 10 c.c. of acetone and alcohol. The haemolytic end point was 1 in $12 \cdot 5$.

Case 2. Pulmonary tuberculosis. The same quantity of liver was treated in an identical manner as in Case 1. The haemolytic end point was the same.

Case 3. Acute nephritis. The kidneys were dried, and the extract was prepared with 10 grms. of dried powder in 100 c.c. of alcohol. The residue from the alcoholic extract was treated with acetone for $\mathbf{2 4}$ hours, and then stored in the ice safe and filtered. The haemolytic end point for both the alcohol and the acetone extract was 1 in 30 .

Case 4. Pernicious anaemia. Patient's colour before death was bright yellow, and his blood plasma was a similar colour. The liver when dried was treated in exactly the same way as in the above experiment. The haemolytic end point for the alcohol and acetone extracts was 1 in 35 . 25 c.c. of each extract were evaporated down and the residue was taken up in 5 c.c. of alcohol and acetone, but identical results were obtained in each case.

Case 5. Congenital cholaemia. The spleen was removed at operation, dried, and 10 grms. of the dried splenic tissue were treated with alcohol and acetone respectively. The haemolytic end point for each extract was 1 in 10 .

Case 6. Acute nephritis. An alcoholic extract of the dried kidneys gave a haemolytic end point of 1 in 10 .

Case 7. Splenomegaly, with severe anaemia. The spleen was removed at operation, and the dried splenic tissue gave a haemolytic end point of 1 in 10 with both the alcohol and acetone extracts.

Case 8. Ruptured malarial spleen. An alcoholic extract of the spleen gave a haemolytic end point of 1 in 10. 25 c.c. of this extract were evaporated down, and equal portions of the residue were taken up in 5 c.c. of absolute alcohol and acetone respectively, but an identical haemolytic end point was obtained.

In all these experiments samples of human red cells from cases of malaria, blackwater fever, various infective conditions and normal red cells were employed, but identical results were obtained whichever sample of red cell was used for the experimental enquiry.

The results obtained by extracting the urine and tissues, in the manner already indicated, show that a haemolytic substance or substances are present in the 
tissues and urine in cases of blackwater fever, and that similar substances were not obtained from the tissues in other conditions including malaria. They may be present in both the alcoholic and acetone extracts, although vastly more potent in the acetone, while the alcoholic extracts would appear to be more active when prepared from the urine in cases which recover.

Maclean considers that acetone has an advantage over alcohol in extraction experiments as it dissolves fats and cholesterol, but leaves phosphatides. In practice, however, it is found that acetone is capable of extracting some of the phosphatides, although the amount is very small under the conditions generally employed. Maclean (1918) has considered the results of these experiments on blackwater fever, but is unable to offer an explanation as to the nature of the substance or substances which would induce these results and, therefore, it is most satisfactory to simply record a statement of facts without useless discussion.

Conclusion. In blackwater fever haemolytic substances with active properties can be extracted from the tissues, and to a less extent from the urine, and these substances haemolyse human and animal red cells ${ }^{1}$.

\section{SECTION IV.}

\section{THE EXPERIMENTAL PRODUCTION OF HAEMOGLOBINAEMIA AND} HAEMOGLOBINURIA IN ANIMALS INJECTED WITH IMMUNE SERA.

Numerous experiments on these lines have been completed by various workers on previous occasions. These observations were made, however, so as to compare rapid blood destruction in animals with the clinical entity termed blackwater fever in the human subject.

Several rabbits were injected intravenously with cats' sera obtained by immunising cats with rabbits' red cells. The methods adopted in each experiment were in the main similar, but certain minor alterations were made for the elucidation of various details which it was hoped would help to throw light on the aetiology of blackwater fever.

It is only necessary to refer to three of the experiments in detail as no further information was obtained beyond what is about to be referred to.

Experiment 1. Rabbit 35 . This animal received $6 \cdot 25$ c.c. of immune cat serum in five injections during a period of six days. The red cells dropped from $6,000,000$ to $1,500,000$ per c.mm., the haemoglobin from 100 to 32 per cent., and the leucocytes from 7500 to 4500 per c.mm. Haemoglobinaemia was present. The urine became dark in colour, and gave a spectrum of oxyhaemoglobin. Albumen was present while a few hyaline casts and red cells were seen in a large deposit of débris. When the rabbit's serum and red cells were mixed together auto-agglutination did not occur. Within a period of one week the urine returned to the normal, and the red cells to $4 \frac{1}{3}$ million per c.mm.

1 Andrew Balfour has suggested that blackwater fever is due to an active haemolysin introduced by a biting insect, which acts on red cells already enfeebled in some way, usually by malaria, sometimes by tick fever. See Balfour, A. (1913). Journ. Tropic. Med. and Hygiene, p. 35. 
Experiment 2. Rabbit 36 . This rabbit received 3.5 c.c. of immune cat serum within 72 hours. The red cells dropped from 6,750,000 to $1,400,000$ per c.mm. and the haemoglobin from 100 to 30 per cent. during this period. The rabbit's serum showed haemoglobinaemia, and the urine which was dark in colour contained oxyhaemoglobin. There was a large amount of albumen, abundance of débris, and free-iron present in the urine. The animal died at the end of the third day from the onset of the experiment. The urine in the bladder, at the post-mortem examination, was deep brown in colour and contained oxyhaemoglobin, a large amount of albumen, and numerous granular and epithelial casts. The rabbit was bled just before death but no auto-agglutination was present.

Autopsy. The spleen was deep red, and very friable. The heart was flabby. The bile in the gall bladder was very thick.

Microscopically. Kidneys. The tubules contained coagulated serum, and there was agglutination of red cells and granular débris present. The epithelium of the tubules, more especially of the convoluted, was degenerated, vacuolated, and was being shed. Free-iron was present, and degenerated renal epithelial cells among the débris in the tubules.

Experiment 3. Rabbit 39. This animal received $6 \cdot 75$ c.c. of immune cat serum intravenously in three days with the result that the red cells fell from 6,360,000 to $1,170,000$ per c.mm., and the haemoglobin from 120 to 29 per cent., while the leucocytes dropped from 7500 to 2420 per c.mm. The urine was dark in colour, and gave a spectrum of oxyhaemoglobin. There was a heavy deposit of albumen, abundance of granular casts, débris, and a few red cells. The rabbit died four days from the onset of the experiment. The urine was collected for 24 hours before death, and from the bladder at the autopsy. Each sample was dried, extracted with alcohol and acetone for eight days at $37^{\circ} \mathrm{C}$., filtered, stored in the cold for three days, and the residue was taken up in 5 c.c. of alcohol and acetone. No haemolysis occurred in a dilution greater than 1 in 10 with either extract, and no haemolytic substances were obtained from the dried kidneys. Rabbits' red cells (1 in 20) in saline were employed for these experiments.

Autopsy. There was no bile pigment in the blood serum. The fat was bright yellow. The spleen was large, deep purple, and firm. The liver was very large, pale and mottled, while the bile was unusually thick and viscid. The kidneys were very pale. The urine in the bladder was of a bright yellow colour, and contained a heavy trace of albumen, but no casts were seen.

Microscopical examination. The spleen. The Malpighian corpuscles showed active endothelial cell proliferation. The free-iron reaction was very marked. The iron was deposited in large clumps in the stroma. Agglutination and active phagocytosis of red cells was present.

The renal changes were similar to those met with in blackwater fever.

The liver. Auto-agglutination of red cells was observed, and red cell débris in some of the vessels. Coarse scattered vacuolation of the liver cells existed. Phagocytes containing pigment and iron granules were numerous in the liver sinuses, while diffuse blue staining of these cells also occurred.

\section{Discussion of the results attained.}

The microscopical changes produced in the tissue of rabbits by injections of haemolytic immune sera may be widespread and severe in character, or they may be much less intensive.

Muir and McNee (1912) in their experiments on the production of anaemia by a haemolytic serum did not consider that such sera have any important action on the various organs. In one experiment they refer to areas of necrosis in the liver. It would appear, however, from full reference to their paper 
that the differences in the findings obtained by these observers and myself are not so great as might seem to be the case.

There are many points of similarity between the experimental production of rapid blood destruction in animals and blackwater fever. The microscopical changes in the kidneys for example in an animal which has received injections of immune sera and in a patient who has died of blackwater fever may be identical. Similar appearances may be observed in the liver, spleen, and in the characteristics of the bile.

The changes observed in the blood and urine correspond in typical examples of blackwater fever and in the experimental haemolytic anaemia.

Potent haemolytic substances have not been obtained, however, by extracting the urine and organs of rabbits which had succumbed to an antihaemolytic serum such as occurred in blackwater fever.

Experiments on these lines, however, fail to explain the essential points for which such observations are conducted. A man who is suffering from acute malaria, or who has suffered from many attacks of malaria in the past, is suddenly seized with an acute illness which may be of a fulminating character causing rapid death from severe blood destruction and its consequent effect on the tissues, or the disease may be less severe in character and may end in complete recovery, or the acute illness may subside, but result in a very severe anaemia. The cause of this condition which is termed blackwater fever cannot be elucidated by injecting animals with the sera of immunised animals.

The essential factor-the nature of the haemolytic process in man-is unknown, just as the cause of the more chronic haemolytic conditionpernicious anaemia-is unexplained at the present time.

These experiments, however, are of importance in the elucidation of certain problems in blackwater fever which are dependent upon the blood destruction.

The anaemia produced by the unknown toxin of blackwater fever is very rapid and severe (see Section I), while experimentally, as is shown in rabbits 35, 36 and 39, referred to above, a very severe and rapid anaemia was induced. Robert Muir and McNee have shown, and my experiments confirm their results, that as the individual susceptibility of rabbits varies enormously, it is not possible to make any statement as to the degree of resulting anaemia in relation to the dose of the serum injected. They found that the intravenous injection of a haemolytic serum is often followed by toxic effects which may sometimes lead to a rapidly fatal result, but when the initial effects have passed without fatal result, the animals do well and do not lose weight, and the subsequent phenomena depend upon the degree of blood destructioneither an acute and fatal anaemia follows, or an anaemia which is followed by rapid regeneration.

Extra-cellular and intra-cellular haemolysis are both concerned in blood destruction as William Hunter (1901) insisted upon, but Muir and McNee emphasise that the extra-cellular lysis is the more important factor. 
The findings in blackwater fever coincide in many respects with the experimental results obtained by Robert Muir and his assistants, and others, on experimental anaemia.

In conclusion, rabbits which were rendered intensely anaemic by injecting immune anti-sera intravenously in the manner indicated, did not develop haemoglobinaemia and haemoglobinuria when treated with various quinine preparations intravenously or intramuscularly.

\section{SECTION V.}

\section{ON QUININE IN RELATION TO BLACKWATER FEVER.}

\section{(a) The Administration of Quinine previous to and DURing an Attack of Blackwater Fever.}

Numerous contributions to the subject of quinine treatment for malaria and its relationship to blackwater fever have been made.

Arkwright and Lepper (1918) record that in 15 out of their 16 cases quinine was administered during the period of haemoglohinuria. It was usually given in the form of the bi-hydrochloride in doses of 10 to 15 grains intramuscularly, but some patients received larger doses. It was given also intravenously and orally. These observers state as follows: "We could not detect any evidence that quinine increased or caused a relapse of the haemoglobinuria in our cases."

Hannemann $(1918 b)$ considers that the haemorrhagic state may be due to quinine derivatives-Cinchonine, Chinicine, and Cinchonicine-which act partly locally on the vasomotor system, and partly centrally.

Stephens (1907) states as follows: "It is the combination of inadequate amounts of quinine and a continuance of slight fever from time to time that seems especially to favour the onset of blackwater fever."

Armand-Delille, Paisseau, and Lemaire (1917) regard a prolonged malarial infection (more than six months) and cold weather as the two predisposing conditions of signal importance in the causation of blackwater fever. All their cases, however, are stated to have received preventative treatment with quinine and in most instances curative quinine treatment also.

Stannus' (1913) experience leads him to believe that in the absence of malaria there is no blackwater fever, while he has never seen this disease among those who had not suffered from a previous attack of malaria treated by quinine.

In 13 cases investigated by me, the amount of quinine taken orally within seven days of the attack of blackwater fever was obtained; seven of these cases recovered and six proved fatal. The largest doses administered during the seven days were 240,210 , and 200 grains, and each case recovered, while the remaining cases received amounts varying from 30 to 140 grains. Every case of blackwater fever among the British troops had received quinine treatment at some time previous to the attack, but either the exact dose is unknown or the relationship between the quinine administration and the onset of the attack. There is no evidence among the records at my disposal 
that quinine treatment for malarial infection during the attack of blackwater fever intensified, or prolonged; the haemolytic process.

Matko (1918) has shown that various samples of urine inhibited the haemolytic action of quinine salts in varying degrees. He believed that this inhibitory action was due to acid phosphate of sodium or potassium. In vitro he estimated that the haemolytic effect of $0.04 \mathrm{grm}$. of sulphate of quinine is neutralised by $0.007825 \mathrm{grm}$. of acid phosphate of sodium (free from water of crystallisation). The experiments which Matko arranged on these lines led him to believe that blackwater fever is bound up with the phosphatic metabolism.

On this evidence he decided to treat a case of blackwater fever with acid sodium phosphate as follows:

Male, aged 24, had blackwater fever for 16 hours. He was given 200 c.c. of a 2.5 per cent. solution of acid sodium phosphate, and seven hours later the urine was normal, but a sudden relapse occurred for which 200 c.c. of the phosphate solution were again given. Eight hours later the urine was normal, but another relapse occurred. It was decided, therefore, to give an intravenous injection of equal parts of 6 per cent. acid sodium phosphate and sodium chloride. The haemoglobinaemia ceased forthwith and within four hours the urine was normal. The addition of sodium chloride was made on the supposition that it will counteract rigors or severe pyrexia which may be induced by the phosphate.

(b) On the Haemolytic Action of Quinine Salts in Urine and on the Excretion of Quinine in the Urine in Malaria and Blackwater Fever.

The samples of urine figured in Table A were taken from the nephritis clinique under Prof. Hugh Maclean, at St Thomas's Hospital. The analysis of the albumen content in each sample of urine was made in his Department and is illustrated in the last column in Table A. It will be readily appreciated from these results that the albumen content has no relationship to the

Table A.

\begin{tabular}{|c|c|c|c|c|c|c|}
\hline \multirow[b]{2}{*}{$\begin{array}{l}\text { No. of } \\
\text { case }\end{array}$} & \multicolumn{6}{|c|}{$\underset{\text { Ui-hydrochloride }}{\text { Containing } 1 \% \text { Quinine }}$} \\
\hline & $\begin{array}{l}\text { Urine } \\
1 \text { c.c. }\end{array}$ & 0.5 c.c. ${ }^{*}$ & 0.25 c.c. ${ }^{*}$ & 0.2 c.c.* & 0.1 c.c. ${ }^{*}$ & Albumen \\
\hline 1 & - & C. & I.C.H. & I.C.H. & - & - \\
\hline 2 & - & C. & I.C.H. & M. & - & - \\
\hline 3 & - & I.C.H. & - & - & - & Trace \\
\hline 4 & - & C. & I.C.H. & - & - & Trace \\
\hline 5 & - & C. & I.C.H. & M. & - & + \\
\hline 6 & - & C. & C. & I.C.H. & - & +++ \\
\hline 8 & - & I.C.H. & - & - & - & Trace \\
\hline 9 & - & C. & C. & I.C.H. & - & Trace \\
\hline 10 & - & C. & I.C.H. & M. & - & Trace \\
\hline 11 & - & C. & M. & - & - & - \\
\hline 12 & - & I.C.H. & Trace & - & - & Faint tra \\
\hline
\end{tabular}

* In each experiment normal saline was added up to 1 c.c. (Tables A and B).

0.05 c.c. of a solid suspension of washed human red cells was added to every tube.

All tubes were incubated for one hour at $37^{\circ} \mathrm{C}$. and the results were read after 30 minutes at room temperature.

Abbreviations employed.

C. Complete haemolysis. I.C.H. Incomplete haemolysis. M. Marked haemolysis (a definite deposit of red cells left). Trace. Tinging of solution with haemoglobin. - No haemolysis. 
haemolytic activity of urines treated with quinine in the manner about to be indicated. Each sample which was freshly passed was cleared by centrifugalisation and then bi-hydrochloride of quinine was added to make a 1 per cent. solution. Control tests were made with a 1 per cent. solution of quinine bi-hydrochloride in saline. The untreated urines (1 c.c.) had no haemolytic action on a 5 per cent. suspension of washed human red cells in saline, but those to which quinine was added gave varying results, which will be referred to in detail. In several instances the effect of the addition of the urine was inhibitory, while in some of the cases the inhibition was very marked. No increased haemolytic activity was observed. The results expressed in Table B

Table B.

To compare the action of a 1 per cent. solution of bi-hydrochloride of quinine in urine on a 5 per cent. and a 2 per cent. suspension of washed human red cells in saline.

\begin{tabular}{|c|c|c|c|c|c|}
\hline $\begin{array}{l}\text { No. of } \\
\text { case }\end{array}$ & $\begin{array}{l}\text { Red cell } \\
\text { suspen- } \\
\text { sion } \%\end{array}$ & 0.2 c.c. & 0.15 c.c. & 0.1 c.c. & 0.5 c.c. \\
\hline \multirow[t]{2}{*}{1} & 5 & I.C.H. & M. & - & - \\
\hline & 2 & C. & M. & - & - \\
\hline \multirow[t]{2}{*}{3} & 5 & - & - & - & - \\
\hline & 2 & - & - & - & - \\
\hline \multirow[t]{2}{*}{4} & 5 & - & - & - & - \\
\hline & 2 & I.C.H. & M. & - & - \\
\hline \multirow[t]{2}{*}{8} & 5 & - & - & - & - \\
\hline & 2 & - & - & - & - \\
\hline \multirow[t]{2}{*}{10} & 5 & M. & Faint trace & - & - \\
\hline & 2 & C. & C. & C. & Trace \\
\hline \multirow[t]{2}{*}{11} & 5 & - & - & - & - \\
\hline & 2 & C. & Trace & - & - \\
\hline \multirow[t]{2}{*}{12} & 5 & - & - & - & - \\
\hline & 2 & - & - & - & - \\
\hline
\end{tabular}

Controlled Test with 1 per cent. of same Quinine Preparation in Saline.
$\begin{array}{lll}\text { A } & 5 & \text { I.C.H. } \\ \text { B } & 2 & \text { C. }\end{array}$
M.
C.
C. Trace

were derived from the same samples of urine treated with quinine, but the comparative haemolytic action on a 5 per cent. and a 2 per cent. suspension of washed human red cells was determined. The chief fact derived from these experiments is that most samples of urine to which 1 per cent. quinine bihydrochloride has been added are much less actively haemolytic on a 5 per cent. or 2 per cent. suspension of red cells than saline containing the same quantity of bi-hydrochloride of quinine, but in one instance (case 10) no inhibition occurred ${ }^{\mathbf{1}}$.

In Table $\mathrm{C}$ the results of the analyses of ten samples of urine from malarial patients are recorded which were made by Captain C. E. C. Ferrey, O.B.E.,

1 Similar experiments were made with other samples of urine, but the results were in agreement. 
in the Central Laboratory, Salonika. Each patient was taking 30 grains of the sulphate or bi-hydrochloride of quinine three times daily. The total quantity of urine passed during 24 hours is recorded, together with the total amount of quinine alkaloid extracted, and the resulting percentage of the alkaloid. These results were obtained from various cases of malaria which were under investigation and they serve to illustrate the variable quantities of urine passed by malarial patients in 24 hours, and the wide variation in the amount of quinine which is extracted. Many more observations were made on the excretion of quinine in the urine of malarial patients, but the results recorded in Table $\mathrm{C}$ are sufficient for the purpose. In the Balkans,

Table C.

The quinine analysis of the urine in ten cases of malaria.

$\begin{array}{cccc}\begin{array}{c}\text { No. of } \\ \text { case }\end{array} & \begin{array}{c}\text { Total volume } \\ \text { of urine } \\ \text { passed in } \\ 24 \text { hours } \\ \text { c.c. }\end{array} & \begin{array}{c}\text { Total amount } \\ \text { of quinine } \\ \text { alkaloid } \\ \text { extracted } \\ \text { gramme }\end{array} & \begin{array}{c}\text { Quinine } \\ \text { alkaloid } \\ \text { in urine }\end{array} \\ 1 & 575 & 0 \cdot 24 & \% \\ 2 & 2240 & 0 \cdot 25 & 0 \cdot 04 \\ 3 & 3110 & 0 \cdot 12 & 0 \cdot 01 \\ 4 & 2130 & 0 \cdot 21 & 0 \cdot 003 \\ 5 & 2490 & 0 \cdot 28 & 0 \cdot 009 \\ 6 & 2900 & 0 \cdot 38 & 0 \cdot 01 \\ 7 & 2105 & 0 \cdot 36 & 0 \cdot 01 \\ 8 & 1530 & 0 \cdot 64 & 0 \cdot 017 \\ 9 & 1850 & 0 \cdot 16 & 0 \cdot 04 \\ 10 & 500 & 0 \cdot 29 & 0.008 \\ & & & 0.06\end{array}$

the extremes of temperature met with have an important bearing on the intake of fluids and the amount which is excreted by the kidneys, and, therefore, on the quinine concentration in the urine. The percentage of quinine excreted in the urine in at least three out of the ten cases is sufficient to excite haemolysis of human or other red cells. Such percentages as 0.06 and 0.04 fall within the limit of quinine concentration capable of exciting haemolysis, when the bi-hydrochloride is dissolved in saline, or even in urine as shown in Table B. Further, we must allow for the fact that quinine bi-hydrochloride contains only 81.6 per cent. of alkaloid. Of course it is possible that quinine is present in greater concentration in the urinary tract at some period of its excretion than the above records show. Marshaux's observation, quoted by Stephens, that "during the period of haemoglobinuria quinine cannot be detected in the urine, but reappears on its cessation," is now known to be incorrect. In Table D the results of the analytical investigations of the urine in cases of blackwater fever are recorded, and in all instances, but one, the observations were made at the height of the haemoglobinuria. In each case, the whole sample of urine passed during 24 hours was collected, thoroughly mixed, and 100-200 c.c. were set aside for the quinine estimation. The percentage of quinine alkaloid obtained in each case is recorded together with the amount of quinine intake 
when it was known. It would be incorrect to make an absolute comparison between the results recorded in Tables $\mathrm{C}$ and $\mathrm{D}$, but the evidence at hand shows that the percentage of quinine alkaloid in the urine in cases of black-

Table D.

\section{Amount of Quinine Alkaloid recovered from the Urine in ten cases of Blackwater Fever.}

The results of the examination of the urine in ten cases are recorded, and are expressed in a tabular form, as follows :

\begin{tabular}{cccc}
$\begin{array}{c}\text { No. of } \\
\text { case }\end{array}$ & $\begin{array}{c}\text { Amount of } \\
\text { urine em- } \\
\text { ployed in } \\
\text { estimation } \\
\text { c.c. }\end{array}$ & $\begin{array}{c}\text { Quinine } \\
\text { alkaloid } \\
\text { in sample } \\
\text { of urine } \\
\%\end{array}$ & \multicolumn{1}{c}{$\begin{array}{c}\text { Amount of quinine administered immediately } \\
\text { preceding or during the acute illness }\end{array}$} \\
18 & 125 & 0.029 & 90 grains in 3 days \\
21 & 150 & 0.009 & 600 grains in 3 weeks immediately preceding attack \\
$22^{*}$ & 145 & 0.046 & $\begin{array}{c}89 \text { grains intravenously and } 30 \text { grains orally during } \\
\text { attack }\end{array}$ \\
24 & 100 & 0.005 & 40 grains in the 24 hours previous to the estimation \\
26 & 125 & 0.029 & No record \\
30 & 125 & 0.006 & 75 grains in last 3 days \\
32 & 125 & 0.009 & No record \\
37 & 200 & 0.017 & No record \\
48 & 200 & 0.005 & 30 grains 3 days previously \\
50 & 170 & 0.0015 & No record \\
52 & 180 & 0.004 & No record
\end{tabular}

water fever during the height of the disease and in malaria may approximate, and that the quinine concentration may be sufficient to excite haemolysis of human red cells.

Nierenstein (1919) described his experimental results with the urine obtained from cases of blackwater fever. He isolated a substance-haemoquinic acid-a disintegration product of quinine, which has pronounced haemolytic properties on human and sheep red cells. The urine from 13 cases of blackwater fever was examined in which this substance was obtained on twelve occasions. Nierenstein suggests that there is a possible relationship between the formation of haemoquinic acid in the organism and the production of blackwater fever, which could be described as a specific quinine "idiosyncrasy" since apparently in blackwater fever haemoquinic acid is produced in larger quantities than in cases of malaria with rigors, the ratio being $578: 1$. He showed in this paper that in 42,000 c.c. of mixed urine from malarial patients the amount of haemoquinic acid obtained was $0 \cdot 3 \mathrm{grm}$., while in 21,000 c.c. of urine from cases with malarial rigors it amounted to $\mathbf{0 . 1 8} \mathrm{grm}$., and in 8400 c.c. of urine from cases without rigors none was found. Contrast the results obtained by Nierenstein in three out of 13 blackwater fever cases where he found (1) 5090 c.c. with 0.36 grm., (2) 1840 c.c. with 0.28 grm., and (3) 3370 c.c. with $0.32 \mathrm{grm}$. No records however are given of the haemolytic action of haemoquinic acid on human or sheep red cells to which reference is made. Further, it must be fully recognised that the haemolytic action of quinine preparations and of other substances in vitro, cannot be taken as an index of haemolysis by the same substances when present in the blood and tissues of man and animals. 


\section{(c) Quinine Administration in Rabbits, in which Complete OCCLUSION OF THE URETERS HAD BEEN PERFormed.}

These experiments were conducted for the purpose of ascertaining whether haemoglobinuria, or a condition similar to blackwater fever, could be induced in rabbits in which the ureters were completely occluded, if quinine was administered intravenously, or intramuscularly, just previous to the ligation, or subsequently. It is well known that quinine is excreted mainly in the urine and to a much less extent by the intestinal tract and by the sweat glands. Hartmann and Zila (1918) consider that 40 per cent. of administered quinine is excreted in the urine and faeces, the rest is not deposited in the organs and must, therefore, be destroyed. After intravenous injection, they state that the amount in the blood sinks rapidly at first and afterwards more slowly, while there is no quinine in the blood eight hours after the injection of $0.5 \mathrm{grm}$. Oral administration, on the other hand, gives a more constant quinine level which is retained for about 24 hours. It was thought possible if sudden suppression of urine was induced in rabbits, and at the same time quinine was administered freely, that in the few days allotted for such experiments haemolytic phenomena might be induced, owing to storage of quinine in the blood and tissues. Five rabbits were selected for these experiments, numbered $a, b, c, d$, and $e$. The abdomen was opened in each case, and both ureters were tied high up near the renal pelvis. Death occurred from the third to the seventh day. Rabbits $a$ and $c$ were used for control purposes. In these animals the ureters were tied, but quinine was not administered, while in the case of rabbits $d$ and $e$ quinine injections were given to the animals intravenously after ligation of the ureters, and with rabbit $b$, before the operation it was injected intramuscularly, and subsequently intravenously. The concentrations of the quinine solutions employed were 1 per cent. and 5 per cent. of the bi-hydrochloride in saline, which are known to actively haemolyse animal red cells in vitro. Quinine administration in man is at times controlled by giving known quantities of the alkaloid per body weight for the treatment of malaria. This method in my opinion is a mistake because two individuals of vastly different weights do not necessarily show any difference in their quinine tolerance. The rabbits employed in these experiments received an excess of quinine on the body weight ratio.

Rabbit $b$. This rabbit was weighed daily for three weeks, and was injected in the various muscles with 1 c.c. of a 1 per cent. solution of bi-hydrochloride of quinine in saline. At the completion of three weeks' quinine treatment, both ureters were tied, and two injections of 1 c.c. of the 1 per cent. solution of quinine were given intravenously. The animal died two days later. The blood was examined during life, but there was no haemoglobinaemia.

Post-mortem examination. Both kidneys were very large, very pale and soft, and showed distension of the ureters proximal to the ligatures, and of the pelvis and calices of each kidney. The fluid obtained from the distended ureters was a reddish brown colour and showed masses of red cells with some slight degree of haemolysis, and conticined numerous epithelial cells. Professor Hugh Maclean extracted $0.0035 \mathrm{grm}$. of alkaloid quinine from 
the concentrated urine. There was no jaundice, and the spleen and liver showed no resemblance to the naked eye changes met with in blackwater fever.

Microscopically. Kidneys. There was no free-iron present. Traces of fine fat droplets were seen in the epithelial cells of the convoluted tubules. There was no resemblance, however, in either kidney to the lesions found in blackwater fever.

Rabbits $d$ and $e$. The ureters of both these rabbits were tied, and then two intravenous injections of 1 c.c. of a 1 per cent. solution of the bi-hydrochloride in saline were given on the day the ureters were occluded, while four subsequent injections, at daily intervals, of 1 c.c. of a 5 per cent. solution of the bi-hydrochloride were employed.

The blood. This was examined on several occasions but there was no haemoglobinaemia, and no bile pigment in the plasma.

Post-mortem examination. One rabbit died in five days and the other in seven days, but the changes found were similar in each instance. The kidneys were very enlarged, very pale, and soft, and contained turbid fluid which distended the pelvis of each kidney and the calices. The deposit in each instance contained hyaline casts and red blood cells and some blood débris, but the urine did not resemble that excreted in blackwater fever. The slight degree of haemolysis which did occur could be explained by the concentration of the urine in the distended pelvis of each kidney. The urine from rabbit $d$, cleared by centrifugalisation and diluted with saline 1 in 5 , showed marked haemolysis in two hours at $37^{\circ} \mathrm{C}$. on a 2.5 per cent. suspension of washed rabbit red cells in saline, but none with a 5 per cent. suspension. The spleens were not enlarged or altered in colour and there were no microscopical changes in the tissues, such as occur in blackwater fever.

The control rabbits, $a$ and $c$, were employed so as to compare the effects on the kidneys and urine of complete occlusion of the ureters apart from quinine administration, but the results were similar. The débris from the pelvis of each kidney showed some red cells, together with epithelial cells, but no casts. There were no changes, however, in the kidneys microscopically as met with in blackwater fever.

Conclusion. The effect of complete occlusion of both ureters in rabbits while quinine is being given or has been given intravenously or intramuscularly does not induce a condition resembling blackwater fever, in any respects.

\section{SECTION VI.}

\section{ON THE EXAMINATION OF THE URINE IN BLACKWATER FEVER.}

1. Agglutination of red cells in the urine in blackwater fever. A study of the microscopical changes in the kidneys in blackwater fever may reveal the presence of "clumped red cells" lying in the lumen of the convoluted and other tubules. The agglutinated red cells may present a striking picture in sections of the kidneys obtained in the acute stages of this disease. For this reason the urine was examined for the presence of agglutinated red cells, which were demonstrated on four occasions. In many instances several samples of urine were examined from the same case. The appearances of the clumped red cells mixed with dark blood stained urine were quite characteristic, although as far as I am aware they have not been referred to previously, while these agglutinated red cells in the urine were found to be very abnormal. 
In each case an identical result was obtained. The clumped red cells were well washed in saline, and then treated with powerful haemolytic agents such as distilled water and bile salts alone or with the addition of calcium. It was found that these red cells showed great resistance to these reagents, and further calcium did not intensify the haemolytic action of bile salts, but induced an opposite effect.

These experiments were carefully controlled because of the exceptional findings, in fact, owing to the increased resistance to haemolysis it was doubted at first whether these particles were really clumped red cells, but the action of bile salts furnished the necessary proof. It would appear, therefore, that red cells which had resisted haemolysis were excreted in the urine, but were protected from haemolytic agents probably owing to the formation of a coat of some colloidal substance.

Dudgeon (1918) has shown, as already stated, that the addition of calcium to bile salts increases their haemolytic action, but in the case of the agglutinated red cells found in the urine in blackwater fever, calcium has an exactly opposite effect.

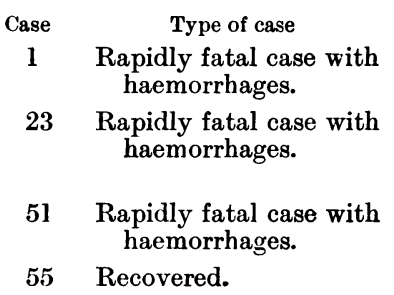

2. On the presence of spirochaetes in the urine. Film preparations were made of the centrifugalised deposit and stained by the original Levaditi method, or that of Fontana Tribondeau, or in those cases in which a very abundant deposit was obtained sections were cut of it after fixation in Kaiserlin and staining the sections by one of the silver methods. No spirochaetes were found, however, by any of the methods employed in the 35 samples of urine investigated. This result corresponds to the negative findings referred to elsewhere when the various tissues were examined from cases of blackwater fever. The absence of spirochaetes from the urinary deposit in every case is also of interest in view of the statements made that the urine in health among the soldiers in the Allied Forces contained spirochaetes apart from any true spirochaetal infection. Fiessinger (1918) considered from his investigations that spirochaetes are found in the urine in about 1 in 45 of normal persons.

In numerous cases, the fresh urine obtained during the height of the attack of blackwater fever was injected intraperitoneally into guinea pigs, while 24 hours' samples of urine were sterilised with ether according to the method of Fildes and Rajchman, before they were used for animal inoculation. No positive results were obtained, however, with any of the samples which were used for inoculation purposes. In one instance a guinea pig which had 
been injected with the urine from a case of blackwater fever showed spirochaetes in the liver. It was the only animal in which spirochaetes were found in the whole series, but unfortunately no transference experiments were made as the organisms were not found until sections had been prepared. In 1917, Major A. L. Urquhart, O.B.E., R.A.M.C., and I carried out certain investigations on cases of sand fly fever in the Struma valley. In these experiments, blood obtained by vein puncture during the height of an attack of sand fly fever, was injected into guinea pigs, and after a definite interval the livers of these pigs were injected into other pigs. Spirochaetes were found in the liver tissue of three pigs which were not related to our experiments. These facts are referred to here because they show that spirochaetes are found in the liver of guinea pigs in conditions of apparent health, and are not necessarily pathogenic. The guinea pigs were obtained from Egypt and Malta and the health of these animals on the whole was about the average.

3. On the presence of acetone and diacetic acid. The urine from 43 cases of blackwater fever was examined for the presence of acetone and diacetic acid at the height of the haemoglobinuria. On 37 occasions the acetone reaction was negative, and positive in six cases, while the reaction for diacetic acid was negative in 39 out of the 43 samples examined. The tests were frequently applied to the fresh samples and to the $\mathbf{2 4}$ hours' specimens. In most instances, the examinations were made by Capt. C. E. C. Ferrey, O.B.E., R.A.M.C., Analytical Chemist to the Army in the Balkans. The large number of negative results for acetone and diacetic acid is of importance. Burkitt (1915) states that the urine is highly acid in blackwater fever and contains acetone, and recommended calcium chloride and potassium or sodium bicarbonate for the treatment of this disease. While at a later date gum arabic 6 per cent. in bicarbonate of sodium has been regarded of the utmost value.

4. On the presence of haemolytic substances in the urine. Urine obtained from many cases of blackwater fever at the onset of the attack was tested on the autogenous and other samples of human red cells other than those from cases of blackwater fever, and sheep red cells. 24 hours' samples of urine were tested after centrifugalisation, and sterilisation with chloroform at $45^{\circ} \mathrm{C}$., on 5 per cent. washed red cells with and without the addition of human or guinea pig complement employed at various dilutions, but in no instance was haemolysis induced. Weak solutions of quinine in saline were added to the sterilised urine and red cells, but no haemolysis occurred.

5. On the injection of the urine from cases of blackwater fever into rabbits. The urine was sterilised at $45^{\circ} \mathrm{C}$. with chloroform, previous to the inoculations.

1. Rabbit 1. Injected intravenously.

$\begin{array}{clc}\text { Date } & \begin{array}{c}\text { Amount } \\ \text { c.c. }\end{array} & \begin{array}{c}\text { Weight } \\ \text { grms. }\end{array} \\ \text { 30. vi. } 18 & 0.75 & 1 \cdot 163 \\ \text { 1. vii. } 18 & 1 & - \\ \text { 2. vii. } 18 & 2 & - \\ \text { 5. vii. } 18 & 1 & - \\ \text { 8. vii. } 18 & 2 & - \\ \text { 12. vii. } 18 & 2 & - \\ \text { 17. vii. } 18 & - & 1.095\end{array}$

The rabbit showed no ill effects from the inoculations and presented no abnormal blood changes. 
2. Rabbit 2. This animal was injected intraperitoneally with the urine from blackwater fever cases sterilised as above.

$\begin{array}{ccc}\text { Date } & \begin{array}{c}\text { Amount } \\ \text { c.c. }\end{array} & \begin{array}{c}\text { Weight } \\ \text { kilos }\end{array} \\ \text { 5. vii. } 18 & 2 & 1 \cdot 150 \\ \text { 8. vii. } 18 & 2 & - \\ \text { 12. vii. } 18 & 2 & - \\ \text { 17. vii. } 18 & - & 1 \cdot 115\end{array}$

This animal showed no ill effects from the inoculations.

The urine employed for these injections into rabbits 1 and 2 was mixed samples obtained from cases of blackwater fever during the acute stages of the disease.

6. On the rapid changes which occur in the urine during an attack of blackwater fever. Very rapid changes occur in the urine in blackwater fever as the disease responds to treatment. Albumen oxy-or met-haemoglobin, and débris which so suddenly appear at the onset of the disease and are followed by an abundance of renal cells and casts, as rapidly disappear, and the urine returns to the normal. The whole process may be completed within a few days. The rapid improvement found in the urine is in accordance with the results of the microscopical examination of the kidneys after blackwater fever, more especially in comparison with the active changes present in cases which have succumbed during the acute stages of the disease.

The changes which the urine undergoes can be divided into three stages as follows:

1st stage. Albuminuria, haemoglobinuria and abundance of débris.

2nd , Abundance of renal cells and casts.

3rd ," The return to the normal.

The records of three cases referred to here are taken from data supplied to me by Capt. J. F. Taylor, R.A.M.C., Pathologist to 52nd General Hospital in the Balkans, to whom I am most grateful.

\section{Case 1.}

\begin{tabular}{|c|c|c|c|}
\hline $\begin{array}{l}\text { Date } \\
\text { iii. } 18\end{array}$ & $\begin{array}{l}\text { Time } \\
\text { hrs. } \\
9.00\end{array}$ & $\begin{array}{l}\text { Amount } \\
\text { c.c. } \\
150\end{array}$ & Analysis \\
\hline 1. 111. 18 & 9.00 & 150 & Dark lager. Albumen. Oxyhaemoglobin débris abundant \\
\hline ", & 11.15 & 130 & , \\
\hline " & 14.5 & 220 & Dark sherry colour, otherwise same \\
\hline ", & 18.30 & 230 & $\begin{array}{l}\text { Pale sherry. Albumen and oxyhaemoglobin as before. Renal } \\
\text { cells and casts abundant }\end{array}$ \\
\hline 8. iii. 18 & 1.00 & 120 & Pale yellow, no albumen, no spectrum, renal casts present \\
\hline , & 11.00 & 160 & " \\
\hline & 19.15 & 140 & Pale yellow, no albumen, no spectrum, no cells, no casts \\
\hline
\end{tabular}

Case 2. Pte B.

23. iii. $18 \quad 10.00-320$

24. iii. $18 \quad 11.00 \quad 200$

$\begin{array}{lll}\text {, } & 14.00 & 527\end{array}$

Dark porter. Albumen. Oxyhaemoglobin. Renal cells. Granular débris. Some granular casts

25. iii. 18 -

26. iii. $18 \quad-\quad-\quad$ Yellow. Albumen faint trace. Large number of cells and

27. iii. 18 -- $\quad-\quad$ Yellow. No albumen. No casts. Few renal cells

29. iii. $18 \quad-\quad-\quad$ Yellow. Urine normal except for few renal cells 
Case 3. Rfl. J.

\begin{tabular}{|c|c|c|c|}
\hline Date & $\begin{array}{l}\text { Time } \\
\text { hrs. }\end{array}$ & $\underset{\text { c.c. }}{\text { Amount }}$ & Analysis \\
\hline 11. xii. 17 & 8.00 & 一 & $\begin{array}{l}\text { Oxyhaemoglobin. Dark red with black granular deposit. } \\
\text { Allbumen }\end{array}$ \\
\hline " & 22.00 & - & No absorption bands present \\
\hline 12. xii. 17 & - & 一 & $\begin{array}{l}\text { Almost normal urine to look at. Albumen. Degenerated } \\
\text { epithelial cells and few granular and epithelial casts. Débris }\end{array}$ \\
\hline 12. xii. 17 & 12.00 & - & Trace of albumen and granular casts. Some débris \\
\hline 13. xii. 17 & - & - & Trace of albumen. Granular casts \\
\hline 19. xii. 17 & - & - & Urine normal \\
\hline
\end{tabular}

Many other cases could be cited which show similar results, but no advantage would be gained by useless repetition.

Red cells which are present in relatively small numbers rapidly disappear from the urine in blackwater fever as the acute stages of the disease subside, but by accurate examinations of centrifugalised samples of urine red cells are found to occur more frequently in the acute stages of the disease than is generally believed or taught. Warrington Yorke, in 1911, refers to the presence of red cells generally in small numbers in the urine during the period of haemoglobinuria.

7. The colour of the urine in blackwater fever. Abnormal variations in the colour of the urine in this disease occur in a more exaggerated degree than in any other known condition in man. The urine may be black or various shades of brown, or deep red in colour. The spectra of oxyhaemoglobin or methaemoglobin are obtained, or both spectra occur in the same sample, one or other in greater proportion.

Burkitt (1919) considers that the "blood red" urine of blackwater fever which gives a spectrum of oxyhaemoglobin only occurs in the worst cases. Barratt and Yorke (1909) showed that only a fraction of haemoglobin injected into the circulation appears in the urine, the rest is employed by the tissues. They also showed that a brownish soluble pigment appears in the urine as the haemoglobin is destroyed which does not give the characteristic spectroscopic bands.

\section{SECTION VII.}

\section{THE SEASONAL INCIDENCE OF BLACKWATER FEVER IN RELATION TO MALARIA AND CLIMATIC CONDITIONS.}

In 53 per cent. of the 100 cases of blackwater fever which form the subject matter of the present communication, the disease occurred during the months of March and April, while during June and July only one case was met with.

Climatic conditions. These records are based on the observations made by the Meteorological Dept. (R.E.) G.H.Q., B.S.F., in 1917 and 1918. The findings for 1916 are omitted for special reasons. In 1917, the absolute maximum temperature for February and the first week in March was at the $60^{\circ}$ level, while the mean temperature varied between $42^{\circ}$ and $46^{\circ}$. During the second week in March the temperature began its upward rise for the summer months. The absolute maximum varied between $64^{\circ}$ and $78^{\circ}$ and the mean daily temperature from $48^{\circ}-60^{\circ}$. In April, the absolute maximum fell between $58^{\circ}$ and $80^{\circ}$, and the mean daily between $53^{\circ}$ and $60^{\circ}$. The wet bulb during the whole of this period was below 65. This brief reference to temperature refers to the observations made in Salonika, but the records taken on the Doiran front were at a slightly lower level, while on the Struma 
front the temperatures during the periods referred to were both slightly below and above the Salonika records. In 1918, the first three weeks of February showed an absolute maximum between $60^{\circ}$ and $67^{\circ}$, and a mean daily which varied between $42^{\circ}$ and $48^{\circ}$, while during the last week in February and the first fortnight in March all temperatures were at a still lower level. The absolute maximum records for the rest of March and April varied between $70^{\circ}$ and $80^{\circ}$ and the mean daily between $47^{\circ}$ and $62^{\circ}$. Both the absolute maximum and the mean daily temperature on the Doiran-Vardar sector and the Struma front were at a slightly lower level than is recorded for Salonika. The wet bulb records at these periods were below 65 . It will be seen from the brief reference to the climatic conditions that the temperature was commencing to rise in March from the low winter records, while at the end of this month and during April the rise was very definite, and it is during this period between the extreme cold of winter and the heat of summer that blackwater fever was most common in the Balkans. As soon as the extreme heat of June and July occurred blackwater fever became a negligible factor.

Malaria. The total deaths from malaria during the months of February, March, and April 1917 were four in number, and for 1918 during the same periods they amounted to twelve. A larger number of deaths occurred in one day in the summer months than in three months in this season of the year. These results clearly show that the lowest death rate from malaria is the period when blackwater fever is at its height. The figures about to be quoted refer to the official returns, and to the findings of the various laboratories attached to the British Force, but the official returns include the cases diagnosed on clinical evidence in addition to those in whom the parasites were found. Both records show, however, that at this season of the year malaria is very largely of the benign tertian type, while further it is figured that the rise in the malarial incidence has definitely begun. The laboratory findings, illustrated in the second and third transverse line of figures, clearly show that blackwater fever occurred at the period of each year when malignant malaria was at its lowest limit. In one week in the late summer months as many as 200-300 cases of malignant malaria would occur.

Malaria. 1917.

$\begin{array}{lrrrrrl}\text { February } & 262 & 217 & 253 & 381 & - & \text { Total admissions } \\ & 89 & 138 & 162 & 214 & - & \text { Benign tertian } \\ & 14 & 7 & 6 & 6 & - & \text { Malignant malaria } \\ \text { March } & 378 & 459 & 470 & 551 & 675 & \text { Total admissions } \\ & 164 & 213 & 246 & 249 & 261 & \text { Benign tertian } \\ & 4 & 25 & 5 & 4 & 4 & \text { Malignant malaria } \\ \text { April } & 568 & 487 & 561 & 617 & - & \text { Total admissions } \\ & 202 & 244 & 281 & 270 & - & \text { Benign tertian } \\ & 1 & 2 & 0 & 0 & - & \text { Malignant malaria } \\ \text { 1918. } & & & & & & \\ \text { February } & 563 & 662 & 744 & 818 & - & \text { Total admissions } \\ & 181 & 203 & 252 & 288 & - & \text { Benign tertian } \\ & 57 & 23 & 2 & 29 & - & \text { Malignant malaria } \\ \text { March } & 882 & 763 & 1059 & 1154 & 1249 & \text { Total admissions } \\ & 348 & 389 & 376 & 387 & 310 & \text { Benign tertian } \\ & 12 & 17 & 5 & 7 & 3 & \text { Malignant malaria } \\ \text { April } & 1510 & 1443 & 1509 & 1172 & - & \text { Total admissions } \\ & 410 & 337 & 380 & 392 & - & \text { Benign tertian } \\ & 0 & 2 & 0 & 0 & - & \text { Malignant malaria }\end{array}$


In conclusion I wish to offer my sincere thanks to my various colleagues in the Balkans during 1916, 17 and 18 for the assistance rendered on numerous occasions. I am especially indebted to Captains C. E. C. Ferrey, O.B.E., Cecil Clarke and Arthur Wilkin, R.A.M.C. and to Corporal F. Panichelli, M.S.M., for constructing suitable apparatus from the limited material at his disposal.

\section{SUMMARY.}

The chief facts learnt from these investigations on blackwater fever are summarised briefly here in the order in which they are detailed in the sections.

1. True jaundice, due to the presence of bile pigment in the plasma, occurred in a high percentage of the cases which ended fatally. Haemoglobinaemia, varying from a deep red coloration of the plasma to a faint tinging, occurred in the acute stages of the disease. There was no evidence of auto-agglutination or auto-haemolysis. The fragility of the red cells was unaltered. No relationship between syphilis and blackwater fever was obtained. Spirochaetes were not demonstrated in the blood in any instance. In the hundred cases in this series, a malarial history was obtained in every instance, and without exception the infection was contracted in the Balkans during 1915-1918. The only blood parasites found were Plasmodium vivax and Plasmodium falciparum.

2. The most important tissue changes were as follows: Fatty degeneration of the myocardium. Reduction of the fat lipoid content of the adrenal gland. Enlargement of the Malpighian corpuscles of the spleen due to various changes in the endothelial centres. Recent or chronic perisplenitis was present in every instance. The other changes in the spleen were numerous and variable and due to blood destruction and malaria. Haemorrhages in the liver tissue and foci of central necrosis, in which reactionary changes had occurred, were met with in many instances. Inspissation of the bile in the gall bladder and bile passages was of common occurrence.

The changes in the kidneys during the acute stages of blackwater fever were very pronounced, but complete recovery rapidly ensued during the period of convalescence without subsequent nephritis as far as the information available indicated. Spirochaetes were not found in any of the tissues in this disease. Scattered haemorrhages occurred in the most rapidly fatal cases.

3. From alcoholic and acetone extracts of the dried residue of the urine, obtained during the period of haemoglobinuria, haemolytic substances were demonstrated. From alcoholic and acetone extracts of the dried organs very active haemolytic substances were obtained, more especially from the acetone extracts.

The alcoholic extracts of the urine were more potent than the acetone in the three cases which recovered. Similar results were not obtained by ex- 
tracting the dried viscera from cases other than blackwater fever, including malaria.

4. There was no evidence that quinine administered by any method during an attack of blackwater fever increased the severity or influenced the progress of the disease apart from its effects on malaria. Quinine administered to animals rendered anaemic did not excite haemoglobinaemia. Quinine was obtained from the urine by extraction, during the period of haemoglobinuria, in amounts which corresponded to those obtained in the malarial cases. Rabbits injected with quinine previous to and during the period when both ureters were ligatured failed to develop haemoglobinaemia or haemoglobinuria.

5. The urine in cases of blackwater fever rapidly returns to the normal from the period of haemoglobinuria. Clumps of red cells which possess certain characteristics were found in the urine in some cases. Clumps of red cells were of common occurrence in the tubules of the kidneys. The injection of sterilised urine from cases of blackwater fever obtained during the period of haemoglobinuria failed to produce any ill effects in animals.

6. Blackwater fever was most frequently met with during the months of March and April, at the time when the temperature was at the commencement of its upward summer rise. No evidence was obtained that blackwater fever is in any way related to anaphylaxis. It was not possible to employ any method to demonstrate whether blackwater fever is due to a filter passer.

\section{REFERENCES.}

ARkwright, J. A. and Lepper, E. K. (18. i. 1918). A series of 16 cases of Blackwater Fever occurring in the Eastern Mediterranean. Trans. Soc. Trop. Med. and Hyg. XI. 127.

Armand-Delinle, Paisseau, S. and Lemaire, E. (28. vi. 1917). Note sur les caractères de la bilieuse hémaglobinurique observée chez lẹs paludéens de l'Armée d'Orient. Bull. et Mém. Soc. Méd. des Hôpit. de Paris, xur. 773.

Barratt, J. O. W. and Yorke, W. (1909). An investigation into Blackwater Fever. Ann. Trop. Med. and Parasitol. $\mathrm{mr} .1$.

BiJon, R. (x. 1915). Etude expérimentale chez l'homme de l'influence de la quinine dans la pathogénie de la fièvre bilieuse hémoglobinurique. Bull. Soc. Pathol. Exot. vIII. 597.

BuRkitT, R. W. (20. xi. 1915). Blackwater Fever. Lancet, II. 1138.

- (20. iv. 1919). The Treatment of Blackwater by intravenous injections of gum arabic.... Pamphlet circulated by Consultant in Malaria. War Office.

Dudgeon, L. S. (1906). A Study of the various changes which occur in the tissues in acute diphtheritic toxaemia. Brain, xxIx. 227.

- (i. 1918). Certain observations on action of Bile and Bile Salts with and withcut the addition of the salts of calcium on animal red blood corpuscles. Journ. of Hygiene, xvi. 240.

- (xi. 1919). On the effects of injections of quinine into the tissues of Man and Animals. Ibid. XviII. 317.

— and Clarke, C. (vii. 1919). An investigation on Fatal Cases of Pernicious Malaria caused by Plasmodium falciparum in Macedonia. Quart. Journ. of Med. xIr. 372.

Fiessinger, N. (1918). Compt. Rend. Soc. de Biol. Paris, LXxxi. 38-40. 
Fletcher, W. (1913). Report on Blackwater Fever. Federated Malay States. 13th Annual Report of the Institute for Medical Research, Kuala Lumpur, 1913.

Hannemann, K. (1918a). München. med. Wochenschr. Lxv. 615-619. (1918b). Ibid. LXv. 665-669.

Hartmann, H. and Zila, L. (1918). The Fate of Quinine in the Organism. Arch. Exper. Pathol. and Pharmacology, Lxxxm. 221.

Hatori, J. (i. 1915). Blackwater Fever in Formosa. Ann. Trop. Med. and Parasitol. viII. 641.

Hunter, W. (1901). Pernicious Anaemia. London: Griffin and Co.

- (1908). "Jaundice"; "Diseases of the Liver" in Allbutt and Rolleston's System of Medicine, Iv. Part 1.

Maclean, H. (1918). Lecithin and Allied Substances. The Lipins. Monographs on Biochemistry. Edited by Plimmer and Hopkins. London: Longmans.

Matкo, J. (17. i.-14. ii. 1918). Ueber Wechselbeziehungen zwischen Harn und Chinin in der Hämolyse. Wien. klin. Wochenschr. xxxr. 65, 130, 188.

Muir, R. and Dunn, J. S. (1915a). The retention of iron in the organs in haemolytic anaemia. Journ. of Pathol. and Bacteriol. xıx. 417.

- $(1915 b)$. The absorption of iron from the organs after haemolysis. Ibid. xx. 41. and McNeE, J. W. (1912). The anaemia produced by a haemolytic serum. Ibid. XVI. 410.

NAPIER, A. H. (x. 1913). Is Syphilis a factor in Blackwater Fever? Indian Med. Gaz. XLVIII. 389.

Nierenstein, M. (iii. 1919). Haemoquinic acid-a new disintegration product of quinine, present in the urine especially in "Blackwater" Fever. Journ. Roy. Army Med. Corps, xxxII. 215.

Paisseau and Lemaire (1916). Bull. Acad. de Méd. de Paris, rxxvi. 300.

Phear, A. G. (1920). Some clinical notes on Blackwater Fever in Macedonia. Journ. Roy. Army Med. Corps, xxxiv. 1.

PlehN, A. (9. vii. 1914). Ein Beitrag zur Kenntnis der akuten hämolytischen Malaria. Deutsche med. Wochenschr. xL. 1414.

Porak, R. (31. v. 1918). Bilieuse hémoglobinurique paludéenne et auto-anaphylaxie. Bull. et Mém. Soc. Méd. des Hôpit. de Paris, xurr. 559.

DE RAADT, O. L. E. (v. 1917). Die Komplementogene Wirkung von Chinin im Zusammenhange mit dem Entstehen des Schwarzwasserfieberanfalles. Archiv f. Schiffs- u. Tropen Hyg. xxr. 149.

SEYFARTH (1918). Ibid. Xxח. 128-145.

Stannus, H. S. (iv. 1913). The Etiology of Blackwater Fever. Trans. Soc. Trop. Med. and Hyg. vI. 181.

Stephens, J. W. W. (1907). See Allbutt's System of Medicine, II. Part 2, p. 289.

— (1913). Studies in Blackwater Fever. Ann. Trop. Med. and Parasitol. vII. 479.

YoRke, W. (1911). Passage of Haemoglobinaemia through the kidneys. Ibid. v. 401. 